\title{
Verpligte koreferensie in Afrikaans: 'n Minimalistiese verkenning
}

\author{
Johan Oosthuizen \\ Departement Algemene Taalwetenskap, Universiteit Stellenbosch, 7600, Stellenbosch, Suid-Afrika \\ E-pos: jo@sun.ac.za
}

\section{Inleiding}

Die "referensiële verhoudings"1 ${ }^{1}$ waarin nominale uitdrukkings met mekaar kan tree is al bykans vier dekades 'n sentrale onderwerp van studie in generatiewe taalondersoek. ${ }^{2}$ Enkele van hierdie verhoudings word geïllustreer deur die uitings in (1).
a. Jan haat homself.
(homself verwys na dieselfde persoon as Jan)
b. Jan haat hom.
( $h o m$ verwys na 'n ander persoon as Jan)
c. Jan sê dat die vrou hom haat.
( hom verwys na 'n ander persoon as Jan)
d. Jan sê dat die vrou hom haat.
(hom verwys na dieselfde persoon as Jan)

Die uitdrukkings Jan in (1a-d) en die vrou in $(1 \mathrm{c}, \mathrm{d})$ is referensieel onafhanklik: op hulle eie kan hulle gebruik word om 'n saak in die werklikheid - 'n referent, hier telkens 'n persoon - te identifiseer. Sulke uitdrukkings staan kortweg bekend as "r(eferensiële)-uitdrukkings". In $(1 \mathrm{~b}, \mathrm{c})$ word die persoonlike voornaamwoord hom eweneens op 'n referensieel onafhanklike manier gebruik. Daarteenoor is die refleksiewe (oftewel wederkerende) voornaamwoord homself in (1a) en die persoonlike voornaamwoord hom in (1d) nie referensieel onafhanklik nie. ${ }^{3}$ Hoewel beide hierdie uitdrukkings referensieel is, word hulle nie op hulle eie gebruik om na 'n referent te verwys nie: hulle verkry eerder hulle verwysing op grond van 'n referent wat geïdentifiseer word deur die gebruik van die r-uitdrukking Jan. Kortom, homself en Jan in 
(1a) en hom en Jan in (1d) het in elke geval dieselfde referent, maar hierdie referent word op verskillende maniere verkry: Jan verkry dit onafhanklik, terwyl homself en hom afhanklik is van Jan vir hulle referent.

Uitdrukkings wat referensieel afhanklik is in 'n sin, staan bekend as "anaforiese uitdrukkings" of kortweg "anafore"; die uitdrukking waarvan 'n anafoor afhanklik is vir sy referent, staan bekend as die anafoor se "antesedent". Die verhouding tussen 'n anafoor en sy antesedent is een van "koreferensie": hulle word gebruik om na dieselfde referent te verwys. Byvoorbeeld, in (1a) is daar 'n koreferensiële verhouding tussen die anafoor - in hierdie geval die refleksief homself - en sy antesedent, die r-uitdrukking Jan. In (1d) word die voornaamwoord hom ook anafories gebruik, aangesien dit in 'n koreferensiële verhouding staan met Jan. In (1b), egter, is daar nie 'n koreferensiële verhouding tussen hom en Jan nie; hier word die voornaamwoord dus nie anafories gebruik nie. Let op dat refleksiewe, anders as voornaamwoorde, nie referensieel onafhanklik kan optree nie: hulle moet verplig in 'n koreferensiële verhouding tree met ' $n$ geskikte antesedent. Die uiting in (1a) sou dus onaanvaarbaar wees indien homself en Jan gebruik word om na verskillende referente te verwys.

'n Toereikende grammatikale analise van referensiële verhoudings soos dié geïllustreer in (1) moet antwoorde verskaf op vrae soos onder meer die volgende:

(2) Met watter middele kan die onderskeiding tussen anafore, voornaamwoorde en ruitdrukkings beskryf word?

(3) Met watter middele kan die vaslegging van 'n koreferensiële verhouding tussen 'n anafoor - spesifiek, 'n refleksief - en sy antesedent verklaar word?

Hierdie artikel fokus op 'n onlangse analise van die referensiële verhoudings tussen nominale uitdrukkings wat deur Heinat (2005, 2006a, 2006b) voorgestel is. In afdeling 3 word daar teen die agtergrond van die vrae in (2) en (3) 'n kort uiteensetting van Heinat se analise gegee. Enkele potensieel problematiese aspekte van dié analise word bespreek in afdeling 4. In afdeling 5 word nagegaan of Heinat se voorstelle 'n toereikende raamwerk bied vir die analise van twee instansies van verpligte koreferensie in Afrikaans. Die bevindings van afdelings 4 en 5 word saamgevat in afdeling 6 . Heinat grond sy analise in die raamwerk van Minimalistiese Sintaksis, die mees onlangse teorie van grammatika binne die breë Beginsels-en-Parameters ("Principles and Parameters", P\&P)-benadering tot generatiewe taalondersoek. Die analise 
word spesifiek aangebied as alternatief vir die Bindingsteorie wat geassosieer word met die sogenaamde Regeer-en-Bind ("Government and Binding", GB)-teorie, 'n vroeëre teorie van grammatika binne die P\&P-benadering. Om mee te begin word daar dus as agtergrond in afdeling 2 'n kort uiteensetting gegee van die vernaamste konsepte van die Bindingsteorie.

\section{Bindingsteorie}

Die mees invloedryke generatiewe raamwerk vir die grammatikale analise van die referensiële verhoudings tussen anafore, voornaamwoorde en r-uitdrukkings was die Bindingsteorie wat in Chomsky (1981) voorgestel is en verder ontwikkel is in veral Chomsky (1982, 1985, 1986, 1995b) en Chomsky en Lasnik (1993, in Chomsky 1995a). Wat betref vraag (2) hierbo, stel Chomsky (1982: 78-83) 'n tipologie van nominale uitdrukkings voor wat gebaseer is op die leksikale kenmerke $[\mathrm{a}($ nafoor $)]$ en [p(ronominaal)]; in dié tipologie word anafore beskryf as $[+\mathrm{a},-\mathrm{p}]$, voornaamwoorde as $[-\mathrm{a},+\mathrm{p}]$, en r-uitdrukkings as $[-\mathrm{a},-\mathrm{p}]{ }^{4}$ Wat betref vraag (3), inkorporeer die versie van die Bindingsteorie in Chomsky (1995a) die volgende prosedure vir anafoor-interpretasie: ${ }^{5}$

(4) Gegee 'n lokale domein D, as $\alpha$ 'n anafoor is, interpreteer dit as koreferensieel met 'n k-kommanderende frase in D.

Die prosedure in (4) voorveronderstel die konsep van $\varphi$-kongruensie ("$\varphi$-agreement") (Chomsky: 1995a: 100): die anafoor moet kongrueer/ooreenstem met sy antesedent ten opsigte van die grammatikale (oftewel formele) kenmerke van persoon, getal en geslag, algemeen bekend as "phi $(\varphi)$-kenmerke". ${ }^{6}$ Verder inkorporeer dit die konsep k(onstituent)kommandeer ("c-command"): 'n anafoor moet deur sy antesedent k-kommandeer word, waar k-kommandeer die volgende inhou: ${ }^{7}$

(5) $\quad \beta$ k-kommandeer vir $\alpha$ indien $\beta$ nie vir $\alpha$ domineer nie, en elke $\gamma$ wat vir $\beta$ domineer ook vir $\alpha$ domineer. ${ }^{8}$

Die presiese inhoud van die uitdrukking "lokale domein" in die interpretasie-prosedure in (4) was, en is steeds, 'n grondliggende kwessie in navorsing oor die referensiële verhoudings tussen nominale uitdrukkings. In die geval van anafore, hou "lokaal" ruweg in dat die antesedent nie "te ver weg" moet wees van die anafoor af nie. Daarteenoor moet 'n 
voornaamwoord wat anafories gebruik word weer nie "te naby aan" sy antesedent wees nie. Beskou ter illustrasie die volgende uitings:

(6) a. Piet sê dat Jan homself haat.

b. Piet sê dat Jan hom haat.

Die refleksief in (6a) kom in terme van $\varphi$-kenmerke ooreen met sowel Piet as Jan, en dit word verder ook k-kommandeer deur beide dié r-uitdrukkings. Tog kan net Jan as antesedent van homself optree: (6a) is onaanvaarbaar as homself geïnterpreteer word as koreferensieel met Piet. Anders gestel, Piet is "te ver weg" van homself af om as antesedent op te tree. Die teenoorgestelde geld in (6b). Dié uiting is onaanvaarbaar indien hom geïnterpreteer word as koreferensieel met Jan: hier is Jan "te naby aan" hom om as antesedent op te tree. Die voornaamwoord kan egter wel gebruik word om te verwys na dieselfde referent as Piet. ${ }^{9}$

In die Bindingsteorie is die beperking op die "afstand" tussen voornaamwoorde en anafore enersyds en hulle moontlike antesedente andersyds uitgedruk in terme van die konsep regering ("government"), en is "lokale domein" gelyk gestel aan "regerende kategorie". ${ }^{10}$ Vir die doeleindes van die artikel kan gesê word dat $\alpha$ vir $\beta$ regeer indien $\alpha$ 'n regeerder is wat vir $\beta$ m-kommandeer en daar nie 'n versperring ("barrier") tussen $\alpha$ en $\beta$ voorkom nie. ${ }^{11}$ Voorts kan "regerende kategorie" gedefinieer word soos in (7).

(7) $\quad \beta$ is die regerende kategorie van $\alpha$ indien $\beta$ die minimale kategorie is wat die volgende bevat: $\alpha$ self, 'n regeerder van $\alpha$, en 'n SUBJEK. ${ }^{12}$

Die rol wat die prosedure in (4) speel in die interpretasie van anafore kan nou teen hierdie agtergrond bondig geïllustreer word aan die hand van die (vereenvoudigde) struktuur (8) onderliggend aan die uiting in (6a):

$$
\text { Piet sê [CP dat [IP Jan [I +tempus, +AGR] homself haat]] }
$$

Die regerende kategorie (dit wil sê, die lokale domein) van die refleksief homself in (8) is die ingebedde IP: dit is die minimale kategorie wat homself, 'n regeerder van homself (naamlik die werkwoord haat), en 'n SUBJEK (naamlik AGR) bevat. Die $\varphi$-kenmerke van homself kongrueer met dié van die subjek van die IP, naamlik Jan, en verder k-kommandeer Jan vir homself. Die prosedure in (4) spesifiseer dus dat die refleksief geïnterpreteer word as 
koreferensieel met Jan; dié interpretasie is inderdaad die enigste aanvaarbare een vir die uiting in (6).

Die Bindingsteorie was langer as 'n dekade die toonaangewende teorie vir die beskrywing en verklaring van die referensiële verhoudings waarin nominale uitdrukkings kan tree. Soos genoem is in afdeling 1, vorm hierdie teorie 'n onderdeel van die GB-teorie. Een van die sleutelkonsepte van die GB-teorie - en ook van die Bindingsteorie, soos hierbo duidelik gemaak is - is dié van regering. In die lig van talle nie-triviale konseptuele en empiriese probleme met hierdie konsep - en verskeie ander GB-konsepte soos onder meer D-struktuur en S-struktuur - is daar egter vanaf die vroeë 1990's begin om 'n alternatief vir die GB-teorie te ontwikkel, hoewel steeds binne die P\&P-benadering. ${ }^{13}$ In hierdie teorie, algemeen bekend as "Minimalistiese Sintaksis" (MS), speel regering en verwante konsepte soos regeerder, regerende kategorie en versperring geen rol nie. Dit volg dus dat die meganismes vir die regulering van referensiële verhoudings wat voorgestel is in die Bindingsteorie - spesifiek die verskillende interpretasie-prosedures vir nominale uitdrukkings (kyk (4) en voetnoot 5), of die bindingsbeginsels van die standaard-Bindingsteorie (kyk voetnoot 5) - nie geïnkorporeer kan word in die MS-raamwerk nie. Hierby moet gemeld word dat die Bindingsteorie ook talle empiriese gebreke vertoon. ${ }^{14}$ Sedert die vroeë 1990's is daar gevolglik verskeie voorstelle gemaak vir die ontwikkeling van 'n alternatiewe analise van "bindingsverskynsels" wat hierdie gebreke kan oorkom en wat versoenbaar is met die uitgangspunte en konsepte van MS. ${ }^{15}$ In die volgende afdeling word 'n kort uiteensetting van een van hierdie analises gegee, naamlik dié van Heinat $(2005,2006 \mathrm{a}, 2006 \mathrm{~b}) .{ }^{16}$ Die uiteensetting fokus op daardie aspekte van die analise wat verband hou met die vrae in (2) en (3) hierbo.

\section{Heinat se minimalistiese analise}

Heinat se analise van die koreferensiële verhouding tussen 'n refleksief en sy antesedent berus op twee sentrale hipoteses. Die eerste hipotese betref die onderskeiding tussen refleksiewe en voornaamwoorde. In afdeling 2 is genoem dat hierdie uitdrukkings in die Bindingsteorie verskillende leksikale items verteenwoordig wat van mekaar onderskei word deur die kenmerke [anafoor] en [pronominaal]: refleksiewe is $[+a,-p]$ en voornaamwoorde $[-a,+p]$. Heinat (2006b: 21-8) argumenteer egter dat die verskil tussen refleksiewe en voornaamwoorde nie leksikaal is nie, maar sintakties. Sy hipotese hou in dat refleksiewe en 
voornaamwoorde samestellings is wat uit dieselfde leksikale wortel ("root") لPRON gevorm word; dié wortel bevat geen sintaktiese kenmerke nie, wat beteken dat dit kategorie-neutraal is. ${ }^{17}$ In die loop van 'n sintaktiese afleiding word VPRON saamgestel ("merged") met 'n spesifieke kategorie-vormende hoof. In die geval van voornaamwoorde behoort die hoof tot die kategorie $\mathrm{N}$ en in die geval van refleksiewe tot die kategorie D. Die onderskeiding tussen voornaamwoorde en refleksiewe word dus nie bepaal deur leksikale kenmerke soos [anafoor] en [pronominaal] nie, maar deur die kategorie van die hoof waarmee $\sqrt{ }$ PRON saamgestel word. Kortom, 'n voornaamwoord is 'n afgeleide N, op sy beurt die hoof van 'n NP; dié NP word verder saamgestel met, ten minste, 'n D om 'n nominale uitdrukking oftewel 'n DP te vorm. 'n Refleksief is daarteenoor ' $n$ afgeleide D wat op sy eie die hoof van 'n DP vorm. ${ }^{18}$ Die resultaat van die verskillende saamstelbewerkings kan skematies soos volg voorgestel word (Heinat 2006b: 28):

a. Voornaamwoord-DP

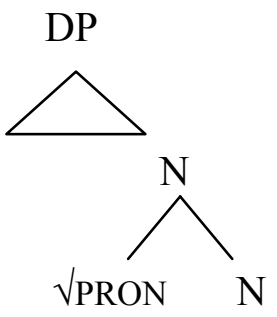

b. Refleksief-DP
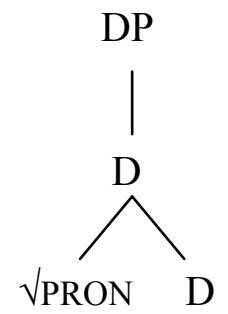

Benewens die kategoriale verskil tussen die hoofde waarmee $\sqrt{ }$ PRON in (9) saamgestel is, verskil hulle ook wat betref die waardes van hulle grammatikale kenmerke. Binne MS het 'n grammatikale kenmerk die eienskap dat dit óf interpreteerbaar óf oninterpreteerbaar is in onderskeidelik die fonologiese en die semantiese komponent van die grammatika. ${ }^{19}$ Alle semanties-oninterpreteerbare kenmerke moet geskrap word in die loop van 'n afleiding om te verhoed dat die afleiding ineenstort; 'n kenmerk kan egter net geïnterpreteer of geskrap word indien dit gewaardeer ("valued") is, dit wil sê, 'n spesifieke waarde het. ${ }^{20}$ In navolging van onder meer Pesetsky en Torrego (2005) maak Heinat (2006b: 26) die aanname dat die grammatikale kenmerke wat 'n rol speel in die afleiding van DP's, die volgende vier tipes insluit: $^{21}$ 
(10) a. $\mathrm{N}$ besit oninterpreteerbare gewaardeerde $\varphi$-kenmerke.

b. $\quad \mathrm{N}$ besit 'n oninterpreteerbare ongewaardeerde K-kenmerk.

c. D besit interpreteerbare ongewaardeerde $\varphi$-kenmerke.

d. D besit 'n oninterpreteerbare ongewaardeerde K-kenmerk.

Die DP's in (9) bevat albei 'n ongewaardeerde K-kenmerk, gelokaliseer in die N/D-hoof

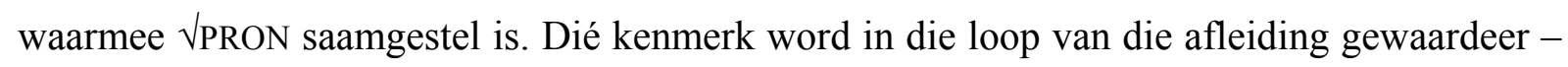
en terstond geskrap ${ }^{22}$ - wanneer die betrokke DP kongrueer met 'n hoof hoër op in die sinstruktuur, waar kongruensie bewerkstellig word in 'n soeker-teiken-verhouding ("probegoal relation"). Die standaard-beskrywing van 'n soeker lui dat dit 'n hoof is met een of meer ongewaardeerde kenmerke wat sy k-kommandeer-domein fynkam vir 'n teiken, waarmee bedoel word 'n element met ooreenstemmende maar gewaardeerde kenmerke wat kan dien om die soeker se kenmerke van waardes te voorsien. ${ }^{23}$ Soos 'n soeker, moet 'n teiken ook ten minste een ongewaardeerde kenmerk hê om aktief te wees, dit wil sê, om betrokke te kan wees in die vaslegging van soeker-teiken-verhoudings. Elemente waarvan al die kenmerke gewaardeer is, is onaktief en kan nie optree as soekers of teikens nie.

Heinat se analise inkorporeer verder die aanname dat twee ooreenstemmende kenmerke F, byvoorbeeld 'n gewaardeerde kenmerk F[g] en 'n ongewaardeerde kenmerk F[o], deur middel van kongruensie 'n kenmerkwaarde-ketting ("feature value chain") vorm, met F[g] se waarde toegeken aan $\mathrm{F}[\mathrm{o}] .^{24}$ Anders gestel, in die notasie $F[2 g] \ldots F[2 g]$... F[5o] vorm die eerste twee F's 'n ketting indien hulle deur kongruensie 'n sekere waarde deel, voorgestel deur die arbitrêre getal [2]. ${ }^{25}$ Veronderstel egter 'n soeker en 'n teiken het dieselfde kenmerk, maar dat dié kenmerk by albei elemente ongewaardeer is. Heinat (2006b: 29) stel dit dat daar in so 'n geval steeds 'n ketting tot stand kom: die twee kenmerke "share the same value if they match and Agree (Agreement can be vacuous)." Dit beteken dat die eerste twee kenmerke in die notasie $F[5 o] \ldots F[5 o] \ldots F[2 g]$ 'n ketting vorm, waar [5] aandui dat hulle dieselfde "geenwaarde" deel; die twee kenmerke kongrueer dus in die opsig dat albei ongewaardeer is.

Die waardering van 'n DP se K-kenmerk kan teen hierdie agtergrond kortliks soos volg beskryf word. Beskou die strukture in (11) hieronder. Aan die een kant het sowel die objekDP in (11a) as die subjek-DP in (11b) 'n ongewaardeerde K-kenmerk; veronderstel verder dat dié DP's behoort tot die tipe in (9a), met ander woorde, dat hulle $\varphi$-kenmerke gewaardeer is. 
Albei DP's is dus aktiewe teikens. Aan die ander kant het die ligte werkwoord ("light verb", voortaan "klein- $v ")$ in (11a) en die $\mathrm{T}$ in (11b) ongewaardeerde $\varphi$-kenmerke; hulle kan dus optree as soekers in hulle k-kommandeer-domeine, onderskeidelik VP en $v$ P. Heinat (2006a: 104-12, 2006b: 30-3) maak verder die aanname dat beide die klein- $v$ en die $\mathrm{T}$ 'n gewaardeerde K-kenmerk het, waar dié kenmerk geassosieer is met akkusatief in die geval van die klein- $v$ en nominatief in die geval van die $\mathrm{T}^{26}$

$$
\begin{array}{ll}
\text { a. } & {\left[{ }_{v \mathrm{P}} v[\mathrm{vP} \ldots \mathrm{DP} \ldots]\right]} \\
\text { b. } & {\left[\mathrm{TP} \mathrm{T}\left[{ }_{v \mathrm{P}} \mathrm{DP} v \ldots\right]\right]}
\end{array}
$$

Kongruensie tussen die DP en die klein- $v$ in (11a) hou in dat die klein- $v$ se $\varphi$-kenmerke deur dié van die DP gewaardeer word en laasgenoemde se K-kenmerk 'n spesifieke waarde kry, naamlik akkusatief. In (11b) hou kongruensie in dat die DP $\varphi$-kenmerkwaardes verskaf aan die $\mathrm{T}$ en die DP se K-kenmerk gewaardeer word as nominatief.

Die twee DP's in (9) verskil nie van mekaar wat betref hulle K-kenmerk nie: in albei gevalle is dié kenmerk aanvanklik ongewaardeer. Die verskil tussen hierdie uitdrukkings lê by hulle $\varphi$-kenmerke. Gegee die verdeling in (10), bevat die DP in (9a) gewaardeerde $\varphi$-kenmerke terwyl dié van die DP in (9b) ongewaardeer is. Dit beteken dat die DP in (9a) nie afhanklik is van enige ander element om sy $\varphi$-kenmerke te waardeer nie; anders gestel, dit tree nie in 'n $\varphi$ kongruensie-verhouding met 'n element waarvan die $\varphi$-kenmerke reeds gewaardeer is nie. Volgens Heinat (2006a: 14-15, 2006b: 27-8) verkry so 'n DP die morfofonologiese vorm van 'n voornaamwoord in die fonologiese komponent, en word dit in die semantiese komponent geïnterpreteer as nie-anafories, dit wil sê, as 'n referensieel onafhanklike uitdrukking.

Beskou nou die DP in (9b). Aangesien sy $\varphi$-kenmerke ongewaardeer is, moet hierdie DP vir die doel van kenmerkwaardering in 'n kongruensie-verhouding tree met 'n element wat gewaardeerde $\varphi$-kenmerke het. Die DP kan wel in 'n $\varphi$-kongruensie-verhouding tree met die klein- $v$ en die $\mathrm{T}$ in die strukture in (11); met ander woorde, daar kan 'n ketting gevorm word tussen die $\varphi$-kenmerke van die DP enersyds en dié van onderskeidelik die klein- $v$ en die T andersyds. In beide gevalle, egter, is dié verhouding leeg ("vacuous") vanuit die oogpunt van $\varphi$-kenmerkwaardering aangesien die klein- $v$ en die $\mathrm{T}$ se $\varphi$-kenmerke ook ongewaardeer is. In die strukture in (11), dus, is daar oënskynlik nie 'n geskikte soeker wat $\varphi$-kenmerkwaardes kan verskaf aan 'n DP van die tipe in (9b) nie. Let op dat hierdie gevolgtrekking berus op die 
aanname dat slegs hoofde - byvoorbeeld klein- $v$ en $\mathrm{T}$ - kan optree as soekers. Volgens Heinat (2006a: 21), egter, is dié aanname bloot 'n stipulasie. In sy kort bespreking van Chomsky (2004a: 113) en Pesetsky en Torrego (2004: 2) se definisies van "soeker" en "teiken" stel hy (2006a: 23) dit nog sterker: "there is no motivation in either definition why only heads with unvalued features are probes, while phrases with unvalued features are not." Die tweede sentrale hipotese van Heinat se analise is dan juis dat soekers nie beperk word tot hoofde nie, maar dat 'n frase wat een of meer hoofde met 'n ongewaardeerde kenmerk domineer, ook kan optree as 'n soeker. ${ }^{27}$ Gegee hierdie hipotese, sou daar dus 'n soeker-teiken-verhouding vasgelê kon word tussen twee DP's mits albei aktief is en die een (die soeker) die ander een (die teiken) k-kommandeer. Gestel die soeker is 'n DP van die tipe in (9a) en die teiken 'n DP van die tipe in (9b). In so 'n geval word die teiken-DP se $\varphi$-kenmerke van waardes voorsien deur die soeker-DP se gewaardeerde $\varphi$-kenmerke. Volgens Heinat (2006a: 14) kan dié geval van $\varphi$-kenmerkwaardering "be said to correspond to co-indexing, or coreferentiality". Heinat (2006a: 14-15, 2006b: 27) stel dit voorts dat 'n teiken-DP wat afhanklik is van 'n soeker-DP vir $\varphi$-kenmerkwaardes, in die semantiese komponent geïnterpreteer word as 'n (refleksiewe) anafoor en die soeker-DP as sy antesedent; die twee DP's se morfofonologiese vorm word ná oordrag deur die meganismes van die fonologiese komponent bepaal.

Die voorafgaande bespreking van Heinat se analise kan meer konkreet gemaak word aan die hand van die uitings in $(1 \mathrm{a}, \mathrm{b})$, hier herhaal as $(12 \mathrm{a}, \mathrm{b})$.
(12) a. Jan haat homself.
b. Jan haat hom.

Beskou eerstens die afleiding van die struktuur onderliggend aan (12b). Die volgende stappe gee 'n vereenvoudigde voorstelling van die verloop van die afleiding. Die eerste stap behels die saamstel van 'n wortel $\sqrt{\text { PRON met }} \mathrm{n}$ kategorie-vormende hoof N; die NP waarvan die afgeleide $\mathrm{N}$ die hoof vorm, word op sy beurt saamgestel met 'n D om 'n DP te vorm, soos getoon in (13). Die afgeleide N, asook die NP en die DP waarvan dit 'n onderdeel vorm, het 'n ongewaardeerde K-kenmerk (kortweg $[\mathrm{K}[2 \mathrm{o}]])$ en gewaardeerde $\varphi$-kenmerke $([\varphi[2 \mathrm{~g}]]){ }^{28}$ 


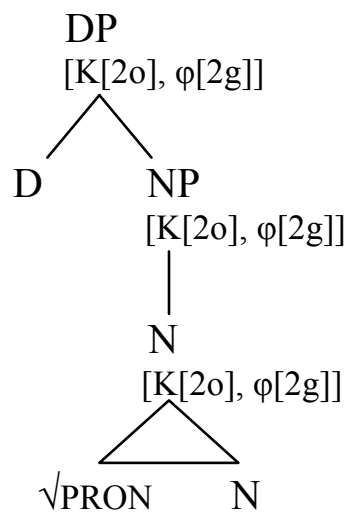

Die tweede stap hou in dat die DP saamgestel word met die oorganklike V haat om 'n VP te vorm, gevolg deur die saamstel van die VP met 'n klein- $v$ :

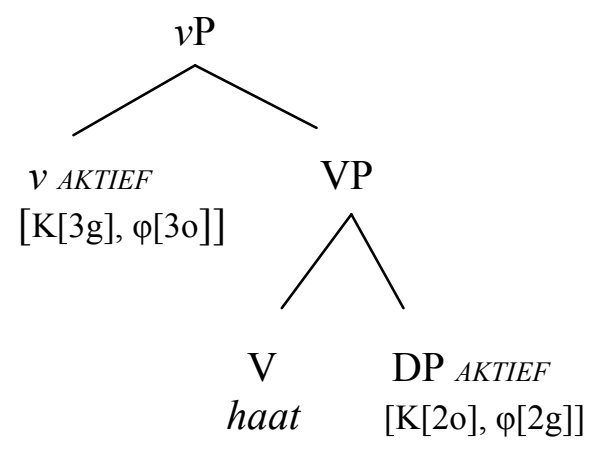

Die klein- $v$ in (14) se ongewaardeerde $\varphi$-kenmerke maak van hom 'n aktiewe soeker wat sy kkommandeer-domein fynkam vir ' $n$ teiken. Die objek-DP is 'n aktiewe teiken, wat beteken dat 'n kongruensie-verhouding tussen die klein- $v$ en die DP vasgelê kan word. Kongruensie hou in dat die klein- $v$ se $\varphi$-kenmerke deur dié van die DP gewaardeer word, en dat die DP se Kkenmerk 'n spesifieke waarde verkry, naamlik akkusatief. ${ }^{29}$ Soos voorgestel in (15), is die klein- $v$ en die DP dus betrokke by twee kenmerkwaarde-kettings: 'n $\varphi$-ketting (aangedui deur [2]) en 'n K-ketting (aangedui deur [3]). Dié kongruensie-bewerkings het tot gevolg dat beide die DP en die klein- $v$ nou onaktief is wat betref verdere soeker-teiken-verhoudings. Die latere oordrag van die VP na die fonologiese en semantiese komponente toe (kyk voetnoot 22) bring mee dat die objek-DP morfofonologies uitgespel word as 'n voornaamwoord (hom in hierdie geval) en semanties geïnterpreteer word as 'n nie-anaforiese uitdrukking, 'n interpretasie wat klop met dié van die uiting in (12b). 
$(15)$

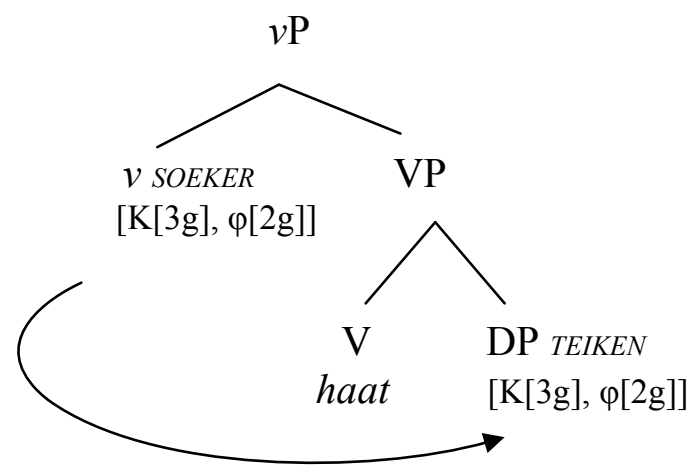

Die volgende stap is die saamstel van die subjek-DP - 'n r-uitdrukking met die NP Jan as onderdeel - in die $v$ P se spesifiseerderposisie. ${ }^{30}$ Beide die DP en die NP het gewaardeerde $\varphi$ kenmerke en 'n ongewaardeerde K-kenmerk. Die uitgebreide $v \mathrm{P}$ word voorts saamgestel met 'n T, wat beskik oor ongewaardeerde $\varphi$-kenmerke en 'n gewaardeerde K-kenmerk; verder kan aangeneem word dat die T ook 'n sogenaamde rand-kenmerk ("edge feature", RK) bevat. ${ }^{31}$ Die effek van die verskillende bewerkings word voorgestel in (16).

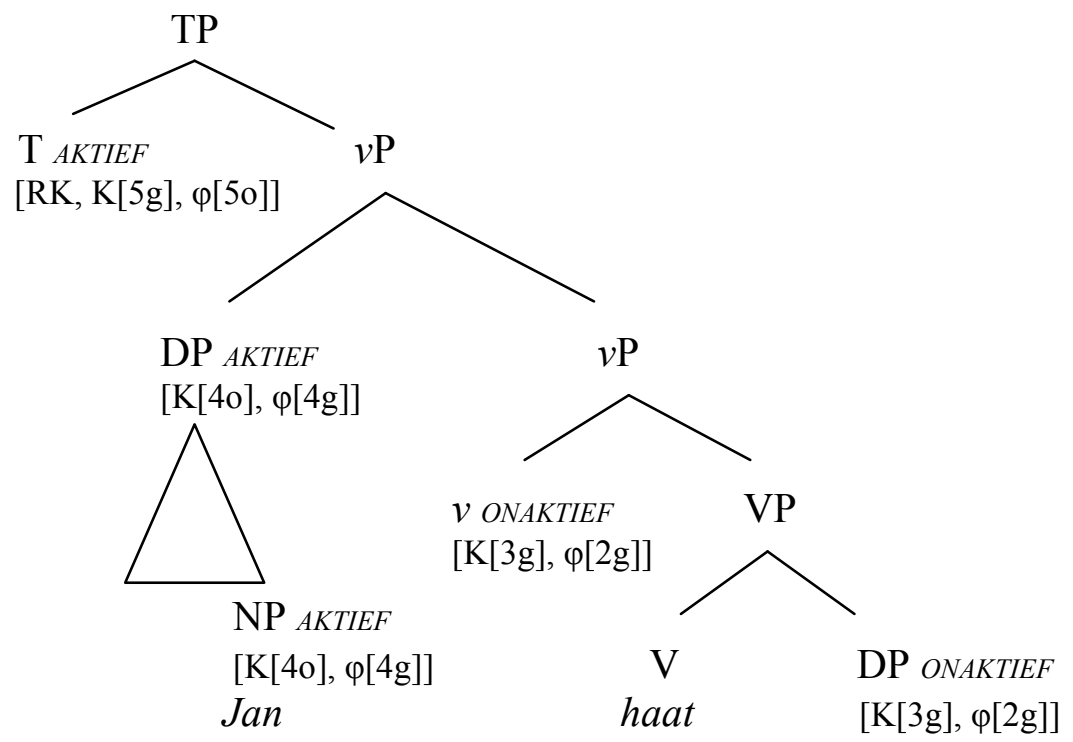

Die $\mathrm{T}$ in (16) tree in 'n kongruensie-verhouding met die subjek-DP. Kongruensie hou in dat die T se $\varphi$-kenmerke van waardes voorsien word en dat die DP (en ook die NP) se K-kenmerk gewaardeer word as nominatief. Die $\mathrm{T}$ en die DP is dus betrokke by twee kettings, soos getoon in (17): 'n $\varphi$-ketting en 'n K-ketting, onderskeidelik aangedui deur [4] en [5]. ${ }^{32}$ 
(17)

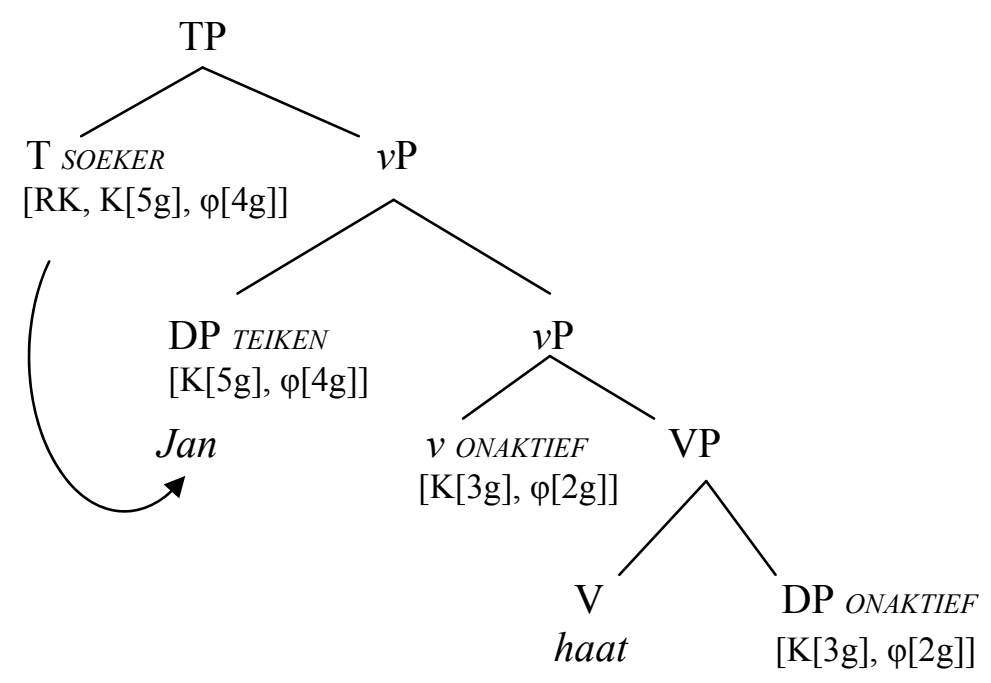

Die $\mathrm{T}$ se rand-kenmerk aktiveer verder die interne saamstel van die subjek-DP in die $\mathrm{T}$ se spesifiseerderposisie; dié bewerking word laastens gevolg deur die saamstel van die TP met 'n $\mathrm{C}$, soos getoon in (18) (waar $<$ DP Jan $>$ die kopie van die verskuifde DP verteenwoordig). ${ }^{33}$

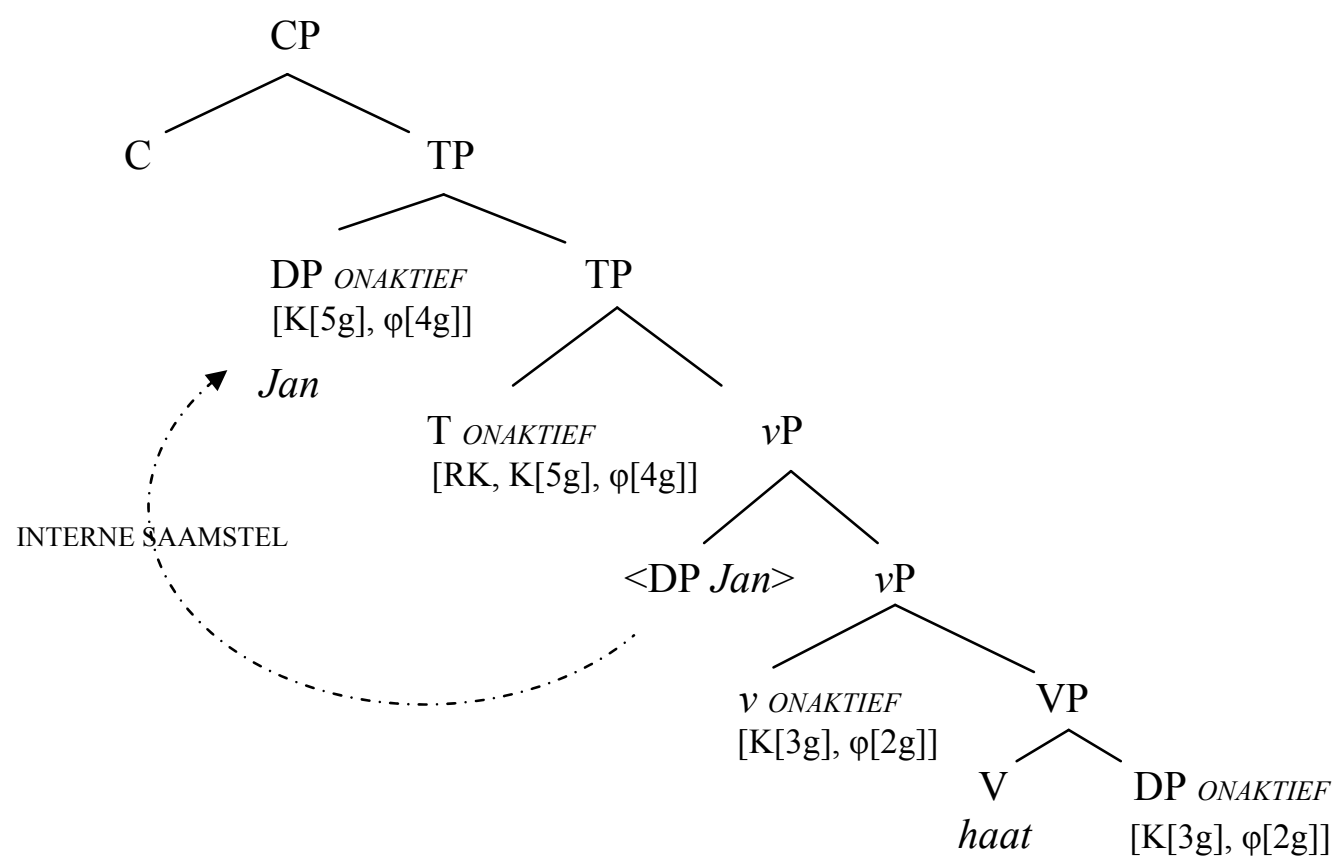

Beskou vervolgens die afleiding van die struktuur onderliggend aan die uiting in (12a). Die eerste stap behels die saamstel van 'n wortel $\sqrt{ }$ PRON met 'n kategorie-vormende hoof D; die afgeleide D vorm op sy beurt die hoof van 'n DP, soos voorgestel in (19). Die afgeleide D, asook die DP waarvan dit die hoof is, het 'n ongewaardeerde K-kenmerk en ongewaardeerde $\varphi$-kenmerke. 
(19)

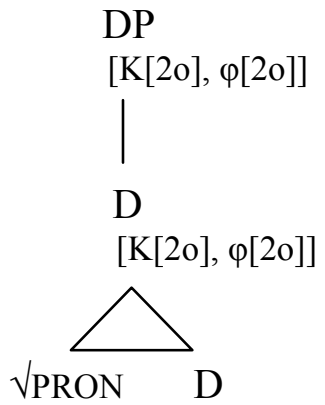

Die DP word nou saamgestel met die oorganklike V haat, gevolg deur die saamstel van die VP met 'n klein- $v:^{34}$

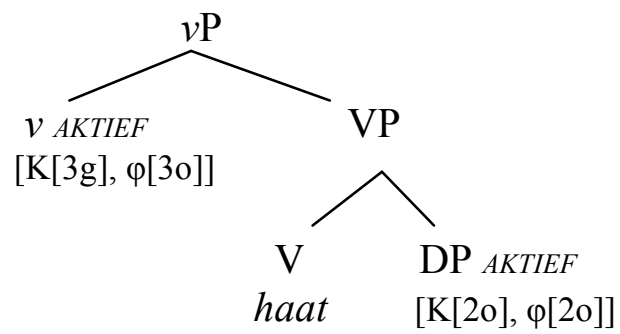

Die klein- $v$ in (20) tree in 'n soeker-teiken-verhouding met die DP. Aangesien beide elemente se $\varphi$-kenmerke ongewaardeer is, hou $\varphi$-kongruensie bloot in dat die $\varphi$-kenmerke van die DP en die klein- $v$ 'n ketting vorm waarin hulle dieselfde "geen-waarde" deel; in die struktuur in (21) hieronder word dié gedeelde waarde aangedui deur [2]. Die feit dat hulle $\varphi$-kenmerke ongewaardeer bly, beteken egter dat die DP en die klein-v steeds aktief is. In die K-ketting, daarteenoor, word die DP se K-kenmerk as akkusatief gewaardeer deur dié van die klein- $v$ (aangedui deur [3]); in die proses word die K-kenmerk van die DP se hoof (kyk (19)) ook gewaardeer, volgens Heinat (2006b: 30).

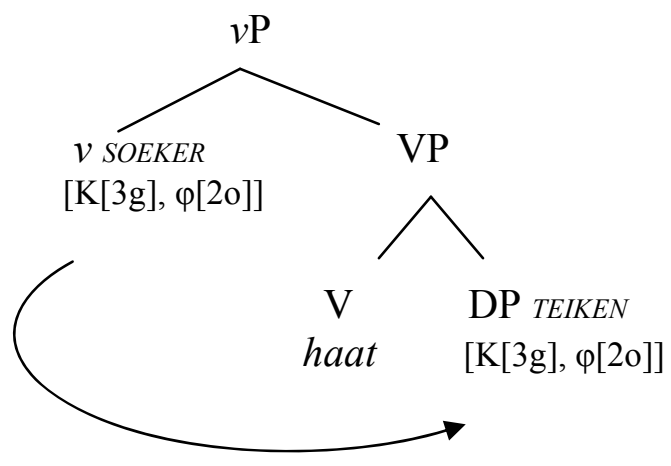


Die subjek-DP, met die NP Jan as onderdeel, word nou in die spesifiseerderposisie van die $v \mathrm{P}$ saamgestel, soos voorgestel in (22). Beide die NP en die DP het gewaardeerde $\varphi$-kenmerke en 'n ongewaardeerde K-kenmerk.

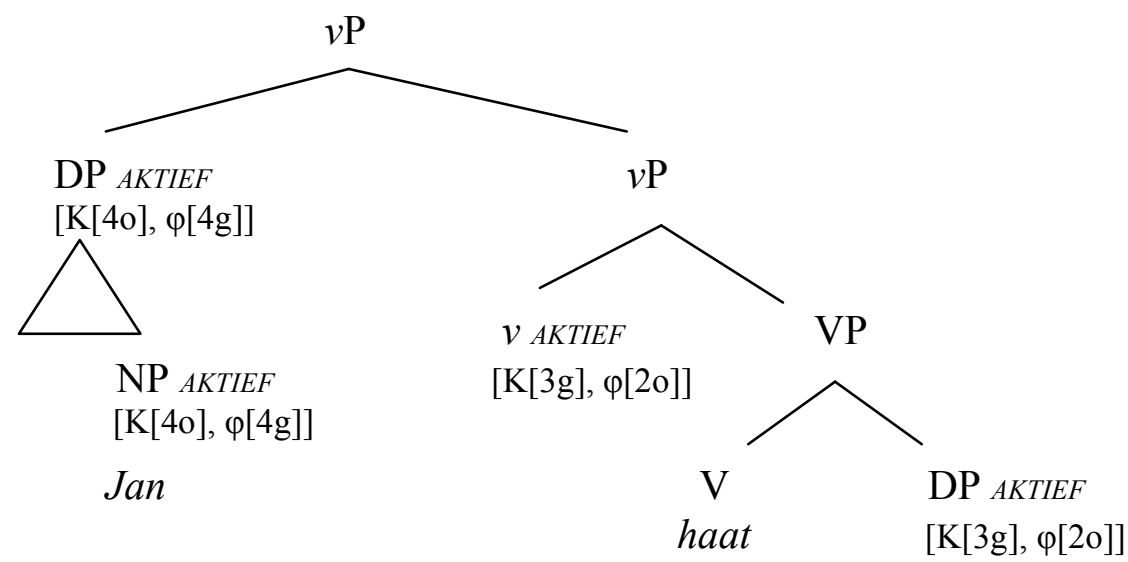

In Heinat se analise verteenwoordig die subjek-DP in (22) 'n soeker wat sy k-kommandeerdomein fynkam vir 'n teiken met 'n gewaardeerde K-kenmerk. Die klein- $v$ is 'n gepaste teiken: dit is aktief, beskik oor 'n K-kenmerkwaarde en word k-kommandeer deur die subjek-DP. 'n Ketting word gevolglik gevorm waarin die subjek-DP se K-kenmerk kongrueer met dié van die klein- $v$, aangedui deur [3] in (23) hieronder. Dit beteken egter dat die subjek-DP se Kkenmerk gewaardeer word as akkusatief, 'n potensieel ernstige probleem vir Heinat se analise in die lig van die feit dat die subjek-DP van 'n finiete sin nominatiewe kasus vertoon. Ons keer terug na hierdie probleem in afdeling 4 .

Vir huidige doeleindes moet hier gewys word op 'n verdere belangrike aspek betreffende Kkenmerkwaardering in 'n struktuur soos (22). Volgens Heinat (2006a: 112, 2006b: 21) is daar 'n soeker-teiken-verhouding tussen die subjek-DP en die klein- $v$, maar nie tussen die onderdele van die DP (in hierdie geval die NP Jan) en die klein- $v$ nie. Die rede hiervoor is dat die NP, hoewel aktief, nie die klein- $v$ kan teiken nie omdat dit nie die klein- $v$ k-kommandeer nie. Die k-kommandeer-vereiste verhoed eweneens dat die klein- $v$, as 'n soeker, enige van die DP se onderdele kan teiken. Dit beteken dat die klein- $v$ nie 'n waarde kan gee aan die Kkenmerk van die NP Jan in (22) nie, ongeag of die klein- $v$ optree as 'n teiken of 'n soeker. Dus, hoewel die subjek-DP deur kongruensie met die geteikende klein-v (oënskynlik) onaktief word, is die NP wat 'n onderdeel van dié DP vorm steeds aktief weens sy ongewaardeerde Kkenmerk. ${ }^{35}$ Let voorts op dat, benewens K-kenmerkwaardering, die teiken-soeker-verhouding tussen die subjek-DP en die klein- $v$ in (22) ook meebring dat die $\varphi$-kenmerke van die klein- $v$ 
gewaardeer word deur dié van die DP. Die gevolg hiervan is dat die spesifieke $\varphi$-waardes wat die klein- $v$ bekom, oorgedra word aan die objek-DP (voorgestel deur die stippelpyl in (23)) omdat die $\varphi$-kenmerke van die klein- $v$ en dié van die objek-DP 'n ketting vorm. Die klein- $v$ en die objek-DP verkry dus deur kongruensie dieselfde $\varphi$-waardes as die subjek-DP, aangedui deur [4] in (23). Soos vroeër genoem, word 'n DP - in die huidige geval die objek-DP - wat van 'n soeker-DP afhanklik is vir sy $\varphi$-waardes, in die semantiese komponent geïnterpreteer as 'n (refleksiewe) anafoor en die soeker-DP as sy antesedent. Hierdie interpretasie klop met dié van die uiting in (12a).

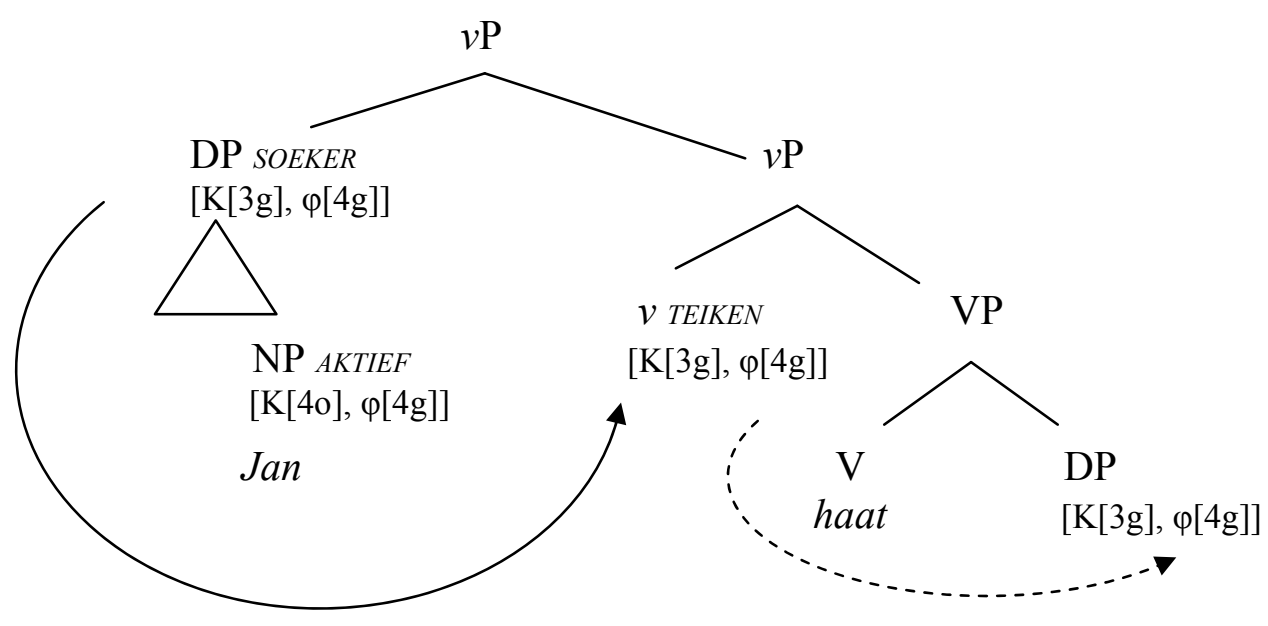

Die volgende stap in die afleiding behels die saamstel van die $v$ P met 'n T, wat beskik oor 'n rand-kenmerk, 'n gewaardeerde K-kenmerk en ongewaardeerde $\varphi$-kenmerke:

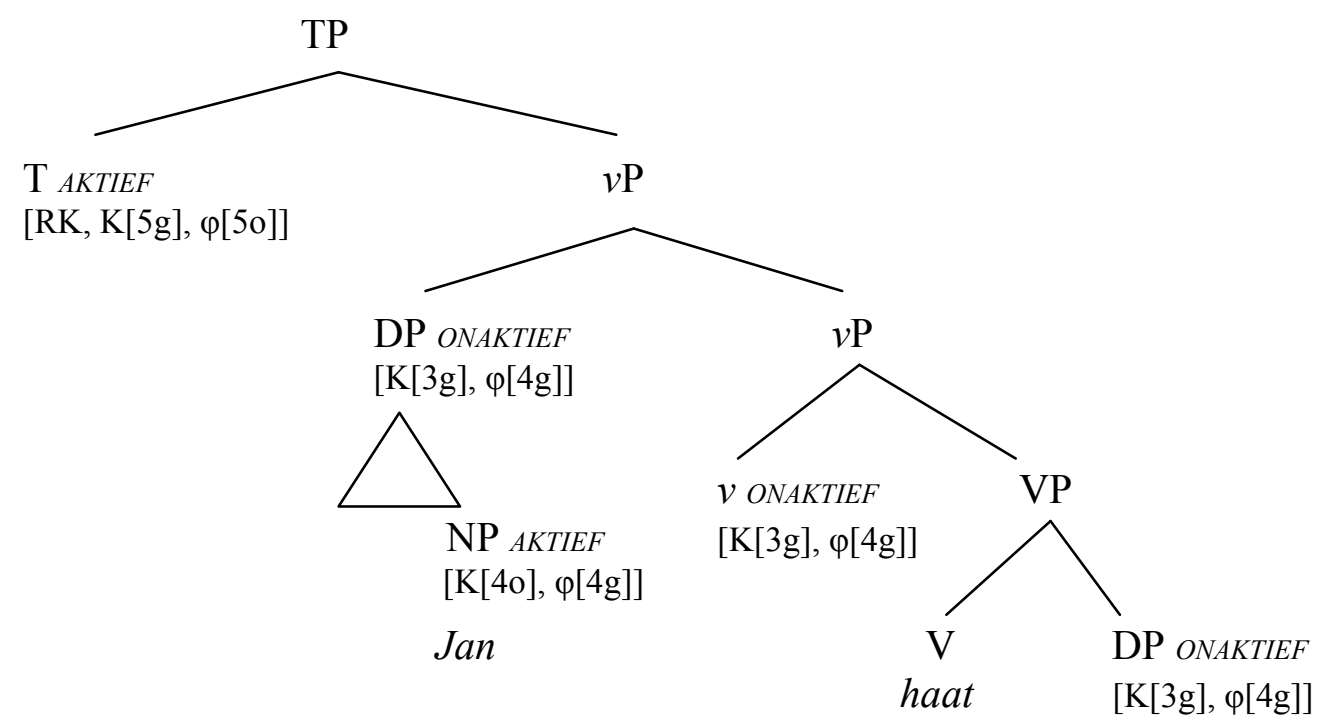


Die $\mathrm{T}$ tree in 'n soeker-teiken-verhouding met die NP Jan, die enigste aktiewe element met gewaardeerde $\varphi$-kenmerke in (24). Kongruensie hou in dat die T se $\varphi$-kenmerke van waardes voorsien word en die NP se K-kenmerk gewaardeer word as nominatief. Die T en die NP is dus betrokke by twee kenmerkwaarde-kettings, 'n $\varphi$-ketting en 'n K-ketting, aangedui deur onderskeidelik [4] en [5] in (25) hieronder. Hoewel die waardering van die NP se K-kenmerk as nominatief op sigself nie problematies is nie, skep dit wel die probleem dat die subjek nou betrokke is by twee verskillende K-waardes: die NP is nominatief, terwyl die bevattende DP akkusatief is deur kongruensie met die klein- $v$. In afdeling 4 word verder aandag gegee aan hierdie kwessie.

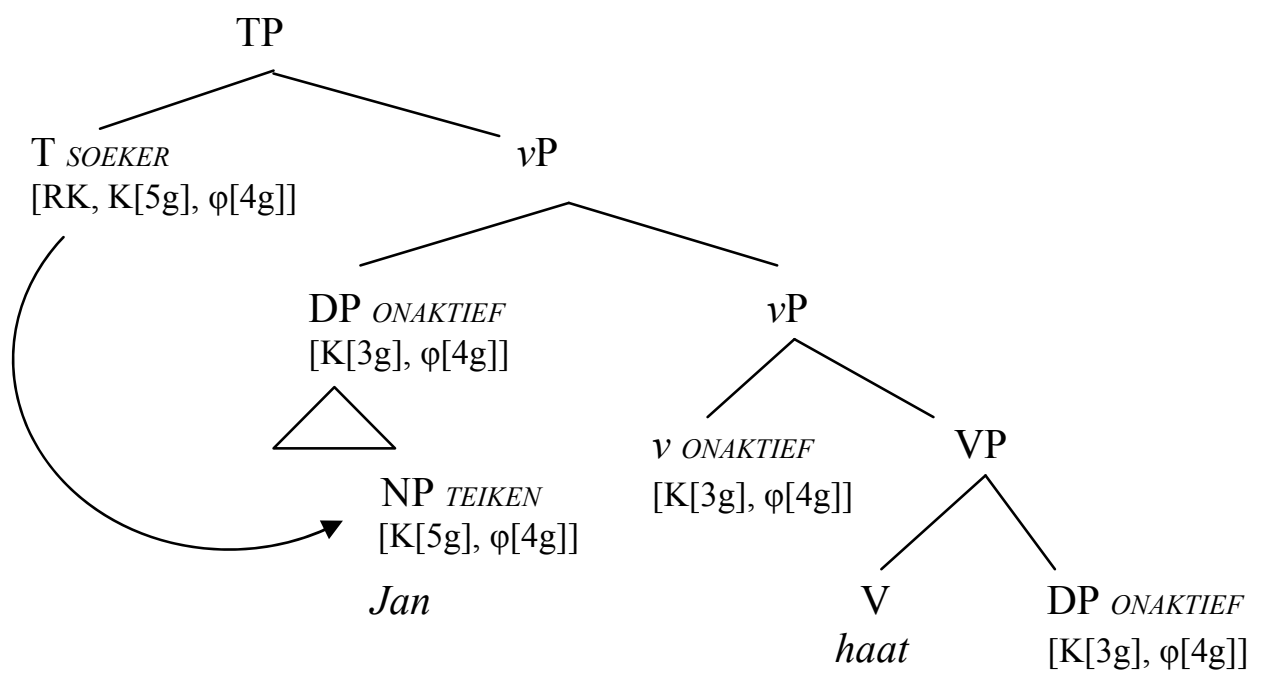

Vervolgens bring die T se rand-kenmerk mee dat die subjek-DP intern saamgestel word in die spesifiseerderposisie van die T, met die TP wat daarna saamgestel word met 'n C: 


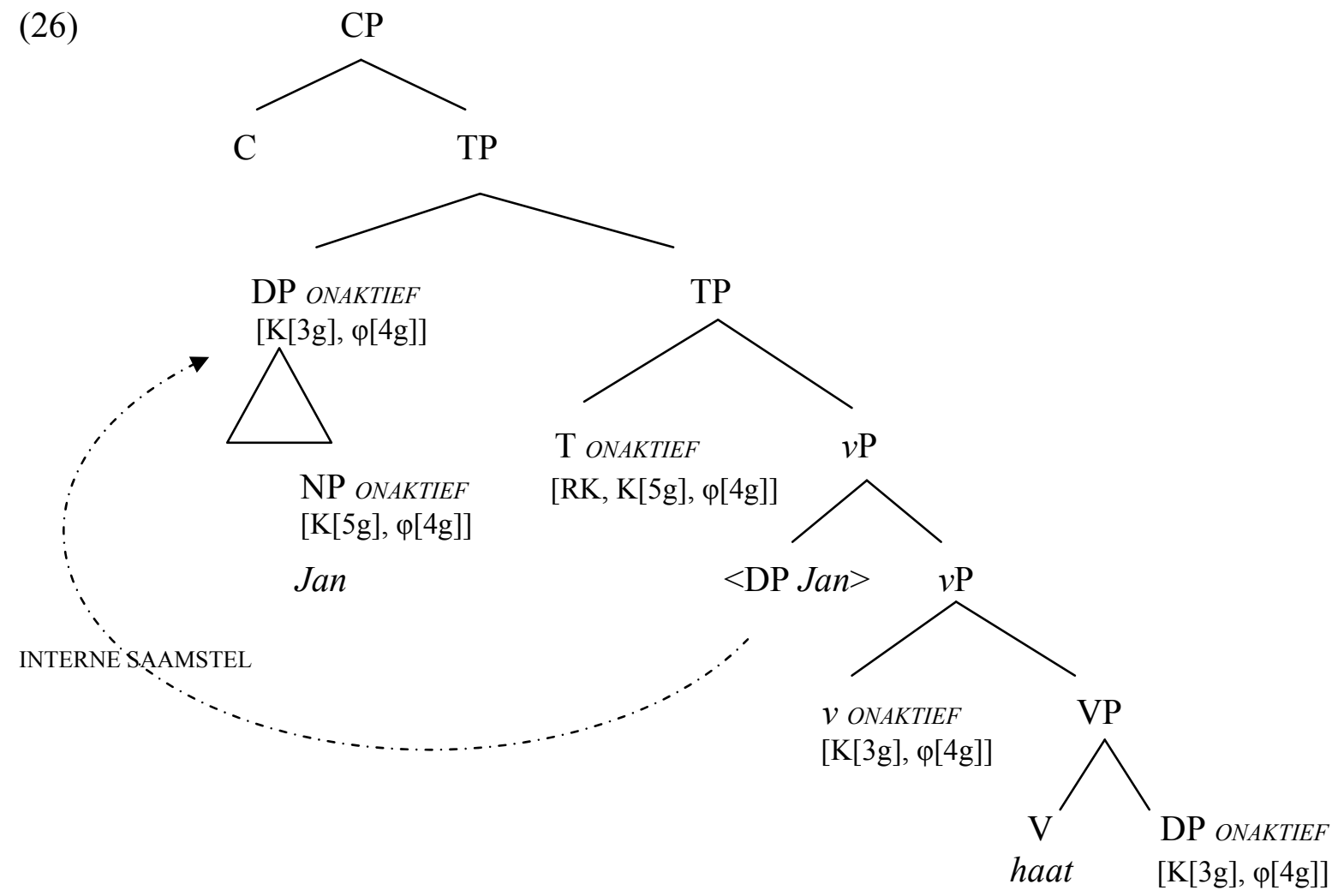

In afdeling 5 word nagegaan of Heinat se voorstelle wat hierbo bespreek is, 'n toereikende raamwerk bied vir die analise van twee instansies van verpligte koreferensie in Afrikaans. Eers, egter, word daar in afdeling 4 aandag gegee aan enkele potensieel problematiese aspekte van Heinat se analise.

\section{Problematiese aspekte van Heinat se analise}

'n Eerste problematiese aspek van Heinat se analise betref die K-kenmerkwaardering van 'n subjek-DP en sy onderdele in finiete sinne met 'n refleksief as objek. Beskou weer die struktuur in (25), hieronder in ietwat gewysigde vorm herhaal as (27). 


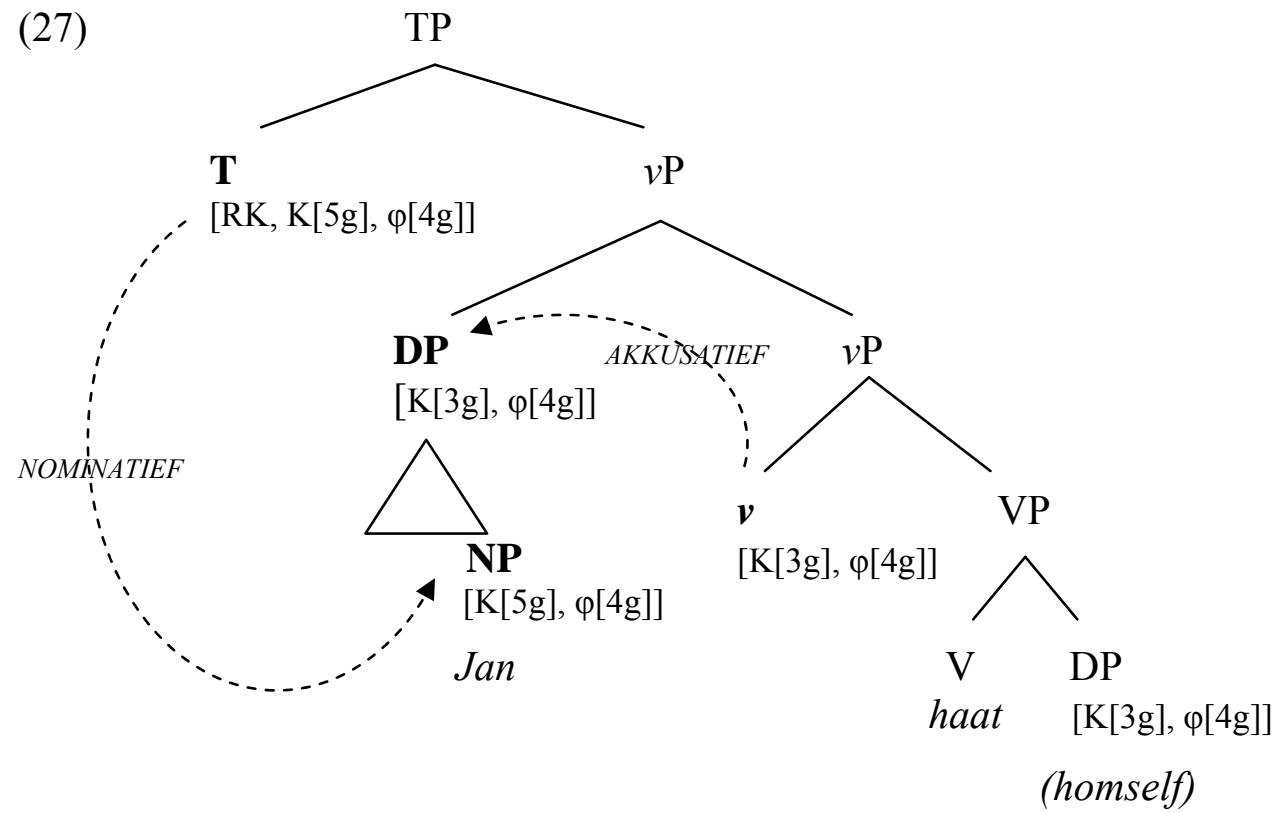

Hierbo is verduidelik dat die K-kenmerk van die subjek-DP in (27) gewaardeer word as akkusatief deur dié van die klein- $v$, terwyl die K-kenmerk van die NP gewaardeer word as nominatief deur dié van die T, soos aangedui deur die stippelpyle. Die probleem hiermee is tweeledig. Enersyds is die subjek betrokke by twee verskillende K-kenmerkwaardes: die DP self is akkusatief, maar dit het as onderdeel ' $\mathrm{n}$ NP wat nominatief is. Andersyds is die DP se akkusatiewe kasus strydig met die feit dat die subjek-DP van 'n finiete sin nominatiewe kasus vertoon.

In aansluiting hierby beweer Heinat (2006a: 113) dat die subjek-DP - ofskoon dit self geen ongewaardeerde kenmerke meer het nie - nogtans steeds aktief is wanneer die $\mathrm{T}$ met die $v \mathrm{P}$ saamgestel word omdat die DP 'n aktiewe onderdeel bevat, naamlik die NP Jan wat op daardie stadium beskik oor 'n ongewaardeerde K-kenmerk. Hierdie bewering is eweneens problematies. In die eerste plek is dit strydig met die algemene aanname dat 'n element waarvan al die kenmerke gewaardeer is - soos die subjek-DP in die huidige geval - onaktief is uit die oogpunt van verdere soeker-teiken-verhoudings. In die tweede plek is dit onduidelik hoe die idee dat die DP aktief bly nadat sy K-kenmerk deur die klein- $v$ gewaardeer is, formeel aangedui kan word as die DP self geen ongewaardeerde kenmerke meer het nie. In die derde plek skep hierdie idee die moontlikheid dat die subjek-DP - soos sy onderdeel, die NP Jan betrokke kan raak in 'n soeker-teiken-verhouding met die T. Dit is dan ook presies wat Heinat voorstel. Volgens hom (2006a: 113) verskaf die T 'n K-kenmerkwaarde aan sowel die DP as 
die NP; in die terminologie van die struktuur in (27) word albei se K-kenmerk dus gewaardeer as $[\mathrm{K}[5 \mathrm{~g}]]$. Dit beteken dat die DP twee K-waardes verkry, naamlik [K[5g],[3g]], met [3g] toegeken deur die klein- $v .{ }^{36}$ Die vraag ontstaan nou of 'n kenmerk wat reeds gewaardeer is, $[\mathrm{K}[3 \mathrm{~g}]]$ in hierdie geval, wel in 'n tweede ketting betrokke kan raak; soos reeds genoem, is 'n gewaardeerde kenmerk veronderstel om onaktief te wees. 'n Verwante vraag is of 'n enkele Kkenmerk twee verskillende waardes kan ontvang. Beskou teen dié agtergrond die volgende opmerking van Heinat (2006a: 113):

(28) Assuming the values on the two Ts to be the same ... there is no clash between them, and at S-O [= "spell-out", die stadium van oordrag na die semantiese en fonologiese komponente toe $-\mathrm{JO}]$ they are deleted. ... As a result we get a converging derivation.

Die uitdrukking "the two Ts" verwys klaarblyklik na die K-kenmerke van onderskeidelik die subjek-DP en die NP. Dit is egter nie duidelik op watter gronde aangeneem word dat die waardes van dié twee kenmerke dieselfde is nie: die subjek-DP het immers twee K-waardes (akkusatief en nominatief) en die NP net een (nominatief). In hierdie verband verwys Heinat (2006a: 115) bloot na Pesetsky en Torrego (2004) se aanname dat daar slegs een waarde vir die K-kenmerk van DP's is en dat "this T feature on DP is structural nominative case." ${ }^{37}$ Dit laat natuurlik steeds die probleem dat die subjek-DP akkusatiewe kasus kry vanaf die klein- $v$.

Heinat (2006a: 113-5) is nie onbewus van die probleem dat die subjek-DP in 'n struktuur soos (27) binne sy analise twee verskillende K-kenmerkwaardes ontvang nie. Hy (2006a: 116) karakteriseer twee moontlike benaderings tot dié probleem, waarvan die eerste soos volg lui ("T" verwys na die K-kenmerk en "Tns" na die funksionele kategorie Tempus):

(29) One solution is that $\mathrm{T}$ on Tns is 'strong' and if a feature gets two values, $\mathrm{T}_{T}$ knocks out $\mathrm{T}_{v}$. One fact that supports such a view is that nominative case, in contrast to accusative case must be assigned (in nom.-acc. languages). If a finite clause has only one argument, for example, passives, unaccusatives and middles, then that argument must be in the nominative even if the semantic interpretation ... suggests that we are dealing with an object that should get accusative case.

Dit is nie duidelik presies wat Heinat bedoel met die uitdrukkings "strong" en "knocks out" in hierdie karakterisering nie, en ook nie hoe die inhoud van elkeen formeel uitgedruk kan word in die grammatika nie. Verder, gegee die voorstel dat die subjek-DP se akkusatiewe kasus "uitgeknikker" word deur die "sterk" nominatiewe kasus wat deur die T toegeken word, is die voor die hand liggende vraag waarom dieselfde nie met die objek-DP se akkusatiewe kasus 
gebeur nie. Per slot van rekening, die objek-DP in (27), net soos die subjek-DP, (i) verkry 'n akkusatiewe K-waarde van die klein- $v$ af, (ii) is onaktief op die stadium dat die T saamgestel word in die struktuur, en (iii) word k-kommandeer deur die T. Die probleem met so 'n bewerking is natuurlik dat die objek-DP dan verkeerdelik sal eindig met nominatiewe kasus.

Heinat (2006a: 113) beweer egter dat die K-kenmerk van die objek-DP in (27) nie deur dié van die $\mathrm{T}$ gewaardeer kan word nie omdat hierdie elemente nie in 'n kongruensie-verhouding kan tree nie, en wel om twee redes. Die eerste is dat die objek-DP geen ongewaardeerde kenmerke besit nie, met ander woorde, dit is onaktief. Dit laat die vraag ontstaan waarom die DP-laag in die subjekposisie (dit wil sê, die DP-etiket op sy eie, uitgesonderd sy onderdele), tog wel in 'n kongruensie-verhouding kan tree met die T: dié DP-laag is immers ook onaktief. Die tweede rede hang saam met die Verbod op Fase-binnedringing ("Phase Impenetrability Condition", PIC), wat bepaal dat 'n soeker buite 'n fase F nie 'n element binne F kan teiken nie, tensy so ' $\mathrm{n}$ element die hoof van $\mathrm{F}$ of ' $\mathrm{n}$ spesifiseerder op die buiterand van $\mathrm{F}$ is. ${ }^{38}$ Volgens Heinat (2006a: 113) het hierdie beperking die effek dat die objek-DP in (27) "inaccessible to Tns" is. Dié siening bots egter met Chomsky (2001: 14) se stelling dat "The probe $\mathrm{T}$ can access an element of the domain YP of HP; the PIC imposes no restriction on this", waar "HP" staan vir $v$ P en "YP" vir VP. Soos genoem in voetnoot 22, is 'n fase-hoof (dit wil sê, $\mathrm{C}$ of $v$ ) se komplement $\mathrm{K}$ nie beskikbaar vir enige verdere sintaktiese bewerkings ná die oordrag van $\mathrm{K}$ aan die semantiese en fonologiese komponente toe nie, waar oordrag plaasvind nadat die volgende fase-hoof in die struktuur saamgestel word. Voordat die C saamgestel word in 'n struktuur soos (27), kan die komplement van die $v$ (dit wil sê, VP) dus steeds binnegedring word deur die $\mathrm{T}$ vir die vaslegging van soeker-teiken-verhoudings. Anders gestel, omdat die $\mathrm{T}$ nie ' $\mathrm{n}$ fase-hoof is nie, bring sy saamstelling met die $v \mathrm{P}$ nie mee dat die VP onbinnedringbaar word nie, anders as wat Heinat (2006a: 113) beweer. ${ }^{39}$

Wat betref die motivering vir die benadering in (29), meld Heinat die verpligte toekenning van nominatiewe kasus in gevalle waar akkusatief op semantiese gronde verwag sou word, byvoorbeeld by die strukturele subjek van passiewe en onakkusatiewe konstruksies. ${ }^{40}$ Pleks daarvan om tussen "sterk" en "swak" kenmerke/kenmerkwaardes te onderskei - soos in vroeëre versies van $\mathrm{MS}^{41}$ - en daarby ook voorsiening te maak vir 'n meganisme om van 'n "ongewenste" akkusatiewe kenmerkwaarde ontslae te raak in die geval van passiewe en onakkusatiewe, sou 'n alternatiewe verklaring gesuggereer kon word in terme van Chomsky 
(2005b, 2006) se onderskeiding tussen twee soorte klein- $v$ 's, naamlik $v$ en $v^{*}$ (kyk voetnoot 26). Om dit kort te stel, daar sou geargumenteer kon word dat passiewe en onakkusatiewe 'n klein- $v$ bevat, wat - anders as 'n klein- $v^{*}$ - nie 'n K-kenmerk het nie (of nie die vermoë het om akkusatiewe kasus toe te ken nie). In sulke gevalle is die objek-DP dus afhanklik van die T vir 'n K-waarde, wat foneties manifesteer as nominatief by passiewe en onakkusatiewe. Die moontlikheid van so 'n verklaring los wel nie die probleem op dat die subjek-DP in 'n struktuur soos (27) binne Heinat se analise twee verskillende K-waardes ontvang nie (een deur die DP-etiket self en een deur sy NP-onderdeel), maar dit plaas wel 'n vraagteken oor die onafhanklike regverdiging van die benadering in (29).

Heinat (2006a: 116) omskryf die tweede benadering tot die pasgenoemde probleem soos volg:

(30) The other solution is that uninterpretable features can have more than one value, the important thing is that they have a value. Since uninterpretable features are deleted before, or at the point of S-O there will not be a semantic clash between the two values. $\mathrm{T}$ is uninterpretable on $\mathrm{DP}$, so if $\mathrm{DP}$ has two different values for $\mathrm{T}$, that is, $\mathrm{T}_{T}$ and $\mathrm{T}_{v}$ it does not lead to a semantic clash/crash since $\mathrm{T}$ will be deleted, not interpreted.

Ook hierdie benadering is problematies, en wel vanuit 'n morfofonologiese oogpunt. Oordrag (oftewel "Spell-out") hou in dat 'n struktuur, spesifiek die komplement van 'n fase-hoof (kyk voetnoot 22), tegelyk gekanaliseer word na die fonologiese en semantiese komponente toe. In die oordrag na die semantiese komponent word 'n DP se oninterpreteerbare K-kenmerk geskrap, mits dit gewaardeer is. Omdat dié kenmerk geen semantiese rol speel nie, sou dit dus argumentshalwe nie saak maak indien dit verskillende K-waardes besit nie. Die probleem is egter dat die K-waardes van DP's wel foneties-interpreteerbaar is: in verskeie tale word die spesifieke morfofonologiese vorm van 'n DP onder meer bepaal deur sy K-kenmerkwaarde. 'n DP met twee verskillende K-waardes sou dus problematies wees vir die meganismes wat 'n rol speel in die bepaling van morfofonologiese vorm, tensy aangevoer word dat een van hierdie waardes op een of ander manier in die fonologiese komponent "uitgeknikker" word. Hierbo is egter reeds gewys op die probleme van so 'n benadering.

Dit behoort duidelik te wees uit die voorafgaande bespreking dat daar potensieel ernstige probleme is met Heinat se voorstelle rondom die K-kenmerkwaardering van 'n subjek-DP in 
'n struktuur soos (27). Teen dié agtergrond sal daar, bloot om die bespreking te vergemaklik, gebruik gemaak word van die volgende werkshipoteses in afdeling 5 hieronder:

(31) Die kategorieë T en klein- $v$ besit albei 'n K-kenmerk, onderskeidelik gewaardeer as nominatief en akkusatief.

(32) Die K-kenmerk van 'n teiken-DP word gewaardeer deur 'n soekende - by implikasie, 'n k-kommanderende - klein- $v$ of T; waardering bring mee dat die DP se K-kenmerk onaktief word.

In terme van die hipotese in (32) word die K-kenmerk van die objek-DP in (27) gewaardeer as akkusatief deur die klein- $v$. Daarteenoor word die K-kenmerk van die subjek-DP - asook dié van sy onderdele, hier die NP Jan - gewaardeer as nominatief deur die T. In al dié gevalle kkommandeer die klein- $v / T$ die element waaraan dit 'n K-waarde verskaf. Let op dat die klein- $v$ - as 'n soeker - nie in 'n kongruensie-verhouding kan tree met die subjek-DP nie omdat dit nie die DP k-kommandeer nie. Dit beteken, volgens die hipotese in (32), dat die klein- $v$ nie 'n Kwaarde aan die subjek-DP kan verskaf nie. Die voordeel van so 'n benadering is dat die subjek-DP nie, soos in Heinat se analise, eindig met twee verskillende K-waardes nie. 'n Moontlike nadeel, egter, is dat 'n K-kenmerk slegs deur 'n k-kommanderende element gewaardeer kan word terwyl so 'n beperking duidelik nie geld vir $\varphi$-kenmerke nie: die nierefleksiewe objek-DP hom in 'n struktuur soos (15) hierbo verskaf byvoorbeeld $\varphi$-kenmerkwaardes aan die klein- $v$, hoewel dit nie die klein- $v$ k-kommandeer nie. Verder moet in gedagte gehou word dat die kenmerke van 'n hoof $\mathrm{H}$ vervat is in sy projeksie HP; die klein- $v$ se Kkenmerk is met ander woorde ook teenwoordig in die $v$ P-etiket. Aangesien die subjek-DP kkommandeer word deur die $v \mathrm{P}$, sou die K-kenmerk van sowel dié DP as sy NP-onderdeel dus deur die $v \mathrm{P}$ gewaardeer kan word as akkusatief. In (32) word hierdie probleem oorkom deur die stipulasie dat slegs hoofde (spesifiek klein-v/T) betrokke is by K-kenmerkwaardering. Dit moet egter beklemtoon word dat die werkshipoteses hierbo, en in die besonder die een in (32), bloot dien om die bespreking in afdeling 5 te vergemaklik.

'n Tweede potensieel problematiese aspek van Heinat se analise betref die kenmerkwaardeketting wat ontstaan wanneer 'n gewaardeerde kenmerk van 'n element A sy waarde toeken aan die ooreenstemmende ongewaardeerde kenmerk van 'n element B. In die struktuur in (27), 
byvoorbeeld, is die subjek-DP (die soeker) en die klein- $v$ (die teiken) betrokke in 'n $\varphi$-ketting, met die DP se $\varphi$-kenmerke wat dié van die klein- $v$ van waardes voorsien (aangedui as $[\varphi[4 \mathrm{~g}]])$. Die waardering van die klein- $v$ se $\varphi$-kenmerke het egter tot gevolg dat die objek-DP se $\varphi$-kenmerke tegelyk dieselfde waardes ontvang, dit wil sê, $[\varphi[4 \mathrm{~g}]]$. Die rede hiervoor is dat die klein- $v$ (as 'n soeker) vóór die saamstel van die subjek-DP reeds 'n $\varphi$-ketting met die objek-DP gevorm het; in hierdie ketting het die twee stelle $\varphi$-kenmerke, op daardie stadium albei ongewaardeer, dieselfde "geen-waarde" gedeel, aangedui as $[\varphi[20]]$ in die struktuur in (22) hierbo. Vir $\varphi$-waarderingsdoeleindes vorm die klein- $v$ en die objek-DP in (27) dus 'n enkele sintaktiese objek; die implikasie is dat die waardering van die klein- $v$ se $\varphi$-kenmerke deur die subjek-DP ook die waardering van die objek-DP se $\varphi$-kenmerke meebring.

Heinat (2006a: 14) beweer die waardering van 'n teiken-DP se $\varphi$-kenmerke deur 'n soeker-DP "can be said to correspond to co-indexing, or coreferentiality." Volgens hom (2006a: 14-15; 2006b: 27) word 'n DP wat sy $\varphi$-kenmerkwaardes van 'n soeker-DP af kry, in die semantiese komponent geïnterpreteer as 'n (refleksiewe) anafoor en die soeker-DP as sy antesedent. Die vraag is egter hoe die betrokke semantiese meganisme "weet" dat die $\varphi$-kenmerke van 'n gegewe DP gewaardeer is deur ' $n$ ander DP in die struktuur. Heinat (2206a: 110) stel dit uitdruklik dat twee DP's met identiese $\varphi$-waardes slegs koreferensieel is as hulle dié waardes in 'n kongruensie-verhouding deel. Byvoorbeeld, in (12b) Jan haat hom het die subjek-DP Jan en die objek-DP hom dieselfde $\varphi$-kenmerkwaardes (derdepersoon, enkelvoud, manlik); tog is hierdie DP's nie in 'n koreferensiële verhouding nie omdat hulle $\varphi$-kenmerke, in Heinat (2006a: 110) se woorde, "have never been in an Agree relation. Each feature gets its own semantic interpretation." Daarteenoor is die DP's Jan en homself in (12a) Jan haat homself binne Heinat se analise wel in 'n koreferensiële verhouding omdat homself se $\varphi$-kenmerke deur dié van die subjek-DP Jan gewaardeer word. Die probleem is egter dat daar op die stadium van oordrag geen formele onderskeiding is tussen die $\varphi$-kenmerke van die objek-DP's in (12a) en (12b) nie. In albei gevalle is die $\varphi$-kenmerke gewaardeer as derdepersoon, enkelvoud, manlik - met geen aanduiding of hulle dié waardes DP-intern of in die loop van die sin se afleiding bekom het nie. ${ }^{42}$ Beskou in hierdie verband ook die volgende stelling van Chomsky se (2005b: 21):

... once features are valued, they are indistinguishable from interpretable features and there is no indication of their relation to the interpretable features that match them and assign them their values. 
Een moontlike benadering tot die bogenoemde probleem het te doen met die getalle wat gebruik word in notasies soos $[\varphi[4 \mathrm{~g}]]$ en $[\varphi[2 \mathrm{o}]]$. Soos gemeld in afdeling 3 , speel dié getalle volgens Heinat (2006a: 110, 2006b: 29) geen rol in kenmerkwaardering nie: "The number is just an indication of a shared value and has no significance in the actual valuation of $\varphi$ features." Dit sluit natuurlik nie die moontlikheid uit dat sulke getalle, indien hulle beskou word as formele onderdele van die afleiding, wel 'n rol speel in semantiese interpretasie nie. Byvoorbeeld, in die struktuur in (27) word die getal [4] gebruik om aan te dui dat die subjekDP Jan en die objek-DP homself deur kongruensie dieselfde $\varphi$-waardes deel. Daar sou dus aangevoer kon word dat die betrokke semantiese meganisme dié getal gebruik as 'n soort "instruksie" om die objek-DP te interpreteer as 'n anafoor en die k-kommanderende subjekDP as sy antesedent.

So 'n benadering is egter nie sonder probleme nie. Veral problematies is die onduidelikheid rondom die status van die getal wat gebruik word in notasies soos $[\varphi[4 \mathrm{~g}]]$ en $[\varphi[2 \mathrm{o}]]$. Heinat (2006a: 110, 2006b: 29-30) spesifiseer byvoorbeeld nie of dit (i) 'n element voorstel wat in die proses van kenmerkwaardering tot stand kom, of (ii) 'n formele (leksikale) onderdeel van 'n kenmerk is, of (iii) bloot 'n soort snelskrif vir 'n bepaalde kenmerkwaarde is nie (dit wil sê, [akkusatief] of [nominatief] in die geval van K-kenmerke, en spesifieke waardes vir persoon, getal en geslag in die geval van $\varphi$-kenmerke). Indien die getal 'n element voorstel wat tydens kenmerkwaardering ontstaan, sou dit 'n oortreding wees van die Insluitingsvoorwaarde ("Inclusiveness Condition"), wat bepaal dat slegs elemente wat uit die leksikon geselekteer is, beskikbaar is vir sintaktiese bewerkings; soos Chomsky (2001: 2) dit stel: "the inclusiveness condition ... bars introduction of new elements ... in the course of computation: indices, traces, syntactic categories or bar levels, etc." ${ }^{43}$ Wat betref die moontlikheid dat die getal in 'n notasie soos $[\varphi[4 \mathrm{~g}]]$ 'n informele voorstelling van bepaalde (gedeelde) waardes is, is dit minstens vreemd dat Heinat dit ook gebruik by ongewaardeerde kenmerke, asook in gevalle waar kenmerkwaardes nie gedeel word nie, wat duidelik nie klop met sy (2006a: 110, 2006b: 29) opmerking hierbo nie.

In die lig van die onduidelikheid rondom die getalle wat gebruik word in die aanduiding van gedeelde kenmerkwaardes, bly dit steeds ' $\mathrm{n}$ vraag hoe daar in die semantiese komponent onderskei kan word tussen 'n DP met intern-gewaardeerde $\varphi$-kenmerke en een wat sy $\varphi$ - 
waardes in 'n kongruensie-verhouding met 'n soeker-DP bekom het. ' $\mathrm{n}$ Moontlike antwoord sou kon lê in die soort bewerking wat deur die betrokke semantiese meganismes uitgevoer word. Soos vroeër verduidelik, is een van die sentrale hipoteses van Heinat se analise dat voornaamwoorde en refleksiewe samestellings is wat uit dieselfde leksikale wortel $\sqrt{ }$ PRON gevorm word. 'n Voornaamwoord word afgelei deur die saamstel van $\sqrt{ }$ PRON met 'n N, en 'n refleksief deur die saamstel van $\sqrt{ }$ PRON met $n$ D. In afdeling 3 is die interne struktuur van voornaamwoorde en refleksiewe voorgestel as onderskeidelik (13) en (19), hier in aangepaste vorm herhaal as (34) en (35).

$$
\text { Voornaamwoord-DP }
$$
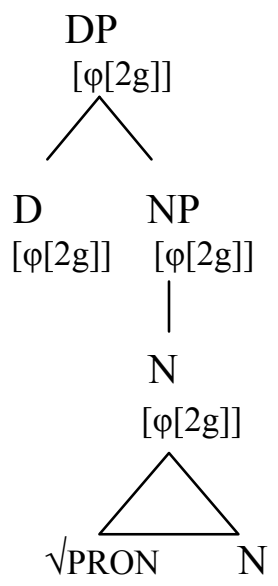

\section{Refleksief-DP}

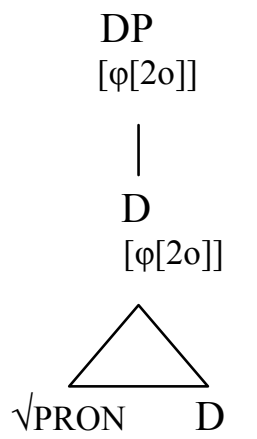

Volgens die tipologie in (10) is 'n N se $\varphi$-kenmerke inherent gewaardeer, terwyl dié van 'n D (aanvanklik) ongewaardeer is. In (34) het die D, en dus ook die DP waarvan dit die hoof is, sy $\varphi$-waardes in 'n soeker-teiken-verhouding gekry vanaf die N. Daarteenoor kry die DP in (35) sy $\varphi$-waardes eers later in die afleiding van 'n gepaste soeker-DP af. Teen hierdie agtergrond sou daar aangevoer kon word dat die semantiese meganismes wat verantwoordelik is vir die regulering van referensiële verhoudings, "gevoelig" is vir die interne struktuur van DP's. Die betrokke meganismes sou die volgende strekking kon hê: ${ }^{44}$

(36) In 'n fase F, as $\alpha$ 'n DP is met 'n NP as onderdeel, interpreteer $\alpha$ as nie-anafories, dit wil sê, interpreteer $\alpha$ as 'n referensieel onafhanklike uitdrukking. ${ }^{45}$ 
In ' $\mathrm{n}$ fase F, as $\alpha$ 'n DP is sonder 'n NP as onderdeel en $\alpha \varphi$-kongrueer met 'n kkommanderende DP $\beta$, interpreteer $\alpha$ as 'n (refleksiewe) anafoor en $\beta$ as sy antesedent, dit wil sê, interpreteer $\alpha$ as koreferensieel met $\beta$.

'n Kritiese bespreking van die meganismes in (36) en (37) val buite die bereik van hierdie artikel; hier word net kortliks gewys op enkele kwessies rondom dié meganismes. Die eerste hou verband met die inligting wat beskikbaar gestel word vir verwerking ("computation") in die semantiese komponent. In MS is sintaktiese bewerkings onderhewig aan die Peuterverbod ("No-Tampering Condition", NTC), wat inhou dat 'n bewerking wat van toepassing is op 'n element E geen verandering (soos byvoeging of skrapping van kenmerke) mag aanbring aan die onderdele van E nie; die interne struktuur van E is dus "buite perke" vir die betrokke bewerking. ${ }^{46}$ Dit is nie duidelik of die NTC ook geld vir die bewerkings van die semantiese komponent nie. Indien wel, blyk dit nie problematies te wees vir die meganismes in (36) en (37) nie: hoewel albei gebruik maak van DP-interne inligting, behels dit nie enige verandering aan die DP se onderdele nie. Beskou egter in aansluiting hierby die volgende stellings van Chomsky (2005a: 14):

(38) Each syntactic object generated contains information relevant to further computation. Optimally, that will be captured entirely in a single designated element, which should furthermore be identifiable with minimal search: its label, the element taken to be "projected" in X-bar-theoretic systems. The label ... should be the sole probe for operations internal to the syntactic object, and the only element visible for further computations.

Hiervolgens moet die inligting wat nodig is vir 'n spesifieke sintaktiese bewerking, optimaal vervat wees in 'n enkele element, een wat met minimale verwerkingskoste geïdentifiseer kan word; volgens Chomsky is sodanige element die kategorie-etiket (D/DP, V/VP, ensovoorts). Dit is nie duidelik of dié stellings ook geld vir semantiese bewerkings nie. Indien wel, is hulle ooglopend problematies vir die meganismes in (36) en (37). In beide gevalle is die inligting wat verskaf word deur die DP - spesifiek inligting oor $\varphi$-waardes - nie genoegsaam om te bepaal of die DP se $\varphi$-kenmerke hulle waardes deur interne waardering of in kongruensie met dié van 'n ander DP verkry het nie. Anders gestel, nie al die nodige inligting is vervat in die DP-etiket nie; om dit te bekom, moet die betrokke meganismes verder soek in die DP se interne struktuur, wat bots met die stellings oor verwerkingskoste in (38). Soos egter genoem, is dit onduidelik of dié stellings ook geld vir die meganismes van die semantiese komponent. 
Beskou vervolgens Chomsky (1995a: 100) se prosedure vir anafoor-interpretasie, geformuleer as (4) in afdeling 2 en geriefshalwe hier herhaal as (39).

(39) Gegee 'n lokale domein $D$, as $\alpha$ 'n anafoor is, interpreteer dit as koreferensieel met ' $n$ k-kommanderende frase in D.

Die meganisme in (37) toon sowel ooreenkomste as verskille met die prosedure in (39). By albei vind die bewerkings wat uitgevoer word in drie stappe plaas: (i) stel vas of 'n DP $\alpha$ in 'n domein $\mathrm{D}$ 'n anafoor is; indien wel, (ii) stel vas of $\alpha \varphi$-kongrueer met 'n k-kommanderende DP $\beta$ in D; en indien wel, (iii) interpreteer $\alpha$ as koreferensieel met $\beta .^{47}$ Die twee benaderings verskil nie wat betref stappe (ii) en (iii) nie. In die geval van stap (ii) inkorporeer beide (37) en (39) die konsep k-kommandeer, en verder hou kongruensie bloot in dat die twee DP's se $\varphi$ kenmerke nie-onderskeibaar moet wees. By stap (i) is daar egter wel wesenlike verskille. In die uitvoering van dié stap is die vertrekpunt met die prosedure in (39) die idee dat anafore identifiseerbaar is op grond van die leksikale kenmerke [+a, -p]; 'n DP met dié kenmerke word dus per definisie geïnterpreteer as 'n anafoor. Met (37), daarenteen, is die vertrekpunt dat 'n DP 'n (refleksiewe) anafoor is as dit nie 'n NP as onderdeel besit nie; meer spesifiek, as dit die struktuur in (35) het. Die prosedure in (39) is dus "gevoelig" vir leksikale kenmerke, en die meganisme in (37) vir DP-interne struktuur. 'n Verdere verskil betref die inhoud van die uitdrukking "domein" in stap (i). Aan die een kant word "lokale domein" in (39) gelyk gestel aan "regerende kategorie" (kyk (7) hierbo). In die geval van (37), aan die ander kant, word die domein waarbinne die bewerking plaasvind, gelyk gestel aan "fase". In die lig van die talle probleme rondom die konsep regering (kyk voetnoot 13), sou die nie-gebruik daarvan om die domein van die bewerking te bepaal waarskynlik beskou kan word as ondersteuning vir die meganisme in (37).

Om saam te vat: binne Heinat se analise bekom 'n DP van die tipe in (35) sy $\varphi$-waardes in 'n kongruensie-verhouding met 'n soeker-DP. Hierdie inligting moet in een of ander vorm beskikbaar wees in die semantiese komponent, anders is daar nie ' $n$ basis vir die interpretasie van die betrokke DP as 'n (refleksiewe) anafoor en die soeker-DP as sy antesedent nie. Sonder so ' $n$ basis is daar duidelik 'n vraagteken oor die meriete van Heinat se analise. Of die meganismes in (36) en (37) dalk 'n oplossing kan bied vir dié probleem, word gelaat as 'n 
onderwerp vir verdere studie. Bloot om die bespreking te vergemaklik, word hieronder gehou by Heinat se gebruik van getalle om gedeelde kenmerkwaardes mee aan te dui.

\section{Twee instansies van verpligte koreferensie in Afrikaans}

Hierdie afdeling handel oor twee tipes konstruksies in Afrikaans wat informeel beskryf kan word as "verplig refleksief". Die vraag is of Heinat (2005, 2006a, 2006b) se voorstelle wat in afdeling 3 uiteengesit is, 'n toereikende raamwerk bied vir die analise van die referensiële verhoudings in dié konstruksies. Beskou, om mee te begin, die uitings in (40). (Uitdrukkings met dieselfde voetskrif verwys na dieselfde referent, en dié met verskillende voetskrifte verwys na verskillende referente; hierdie gebruik van voetskrifte is bloot om die bespreking te vergemaklik.)
a. $\quad \operatorname{Jan}_{\mathrm{i}}$ verset homselfi
b. $\quad \operatorname{Jan}_{\mathrm{i}}$ verset hom $\mathrm{i}$
c. $\quad * \operatorname{Jan}_{\mathrm{i}}$ verset hom . $_{\text {. }}$

Die uiting in (40a) vertoon opvallende ooreenkomste met $\operatorname{Jan}_{\mathrm{i}}$ haat homself in (1a)/(12a): benewens die leksikale en referensiële ooreenkomste ( $\operatorname{san}_{\mathrm{i}}$, homself $f_{\mathrm{i}}$ ), het albei uitings 'n onderliggende struktuur met die vorm [subjek-oorganklike werkwoord-objek]. Die uitings verskil egter van mekaar in twee belangrike opsigte. ${ }^{48}$ Eerstens, die werkwoord in (40a) het die eienskap dat dit "uitsluitlik refleksief" is, waarmee bedoel word dat dit 'n koreferensiële verhouding tussen die objek en die subjek afdwing; of anders gestel, die werkwoord het die sintaktiese eienskap dat dit 'n objek selekteer wat verplig 'n refleksiewe anafoor moet wees, soos getoon deur die verskil in aanvaarbaarheid tussen $(40 \mathrm{a}, \mathrm{b})$ en $(40 \mathrm{c}) .{ }^{49}$ Die werkwoord haat in (12a), daarteenoor, is nie uitsluitlik refleksief nie: dit kan 'n objek selekteer wat nie 'n anafoor hoef te wees nie, soos blyk uit die aanvaarbaarheid van (1b)/(12b) Jan haat hom $_{\mathrm{j}}$. Die tweede verskil tussen uitings van die tipe in $(40 a, b)$ enersyds en (12a) andersyds betref die morfologiese vorm van die objek. In die geval van uitsluitlik refleksiewe werkwoorde, soos verset in (40a), kan die anaforiese objek 'n simplekse vorm óf 'n komplekse vorm hê. Met "simplekse vorm" word bedoel 'n akkusatiewe voornaamwoord op sy eie (my, jou, hom, haar, hulle, ensovoorts) en met "komplekse vorm" 'n akkusatiewe voornaamwoord met -self as agtervoegsel (myself, jouself, homself, haarself, hulself, ensovoorts). ${ }^{50}$ By werkwoorde wat 
nie uitsluitlik refleksief is nie, soos haat in (12), kan die anaforiese objek egter normaalweg slegs 'n komplekse self-vorm hê: (12b) Jan haat hom is byvoorbeeld onaanvaarbaar indien die simplekse vorm hom geïnterpreteer word as 'n anafoor wat koreferensieel is met Jan. ${ }^{51}$

Binne Heinat se raamwerk verloop die afleiding van 'n sin met 'n uitsluitlik refleksiewe werkwoord - spesifiek 'n sin soos dié onderliggend aan (40a/b) - op dieselfde manier as die afleiding van 'n sin waar 'n nie-uitsluitlik refleksiewe werkwoord saamgestel word met 'n anaforiese objek (byvoorbeeld die sin onderliggend aan die uiting in (12a); kyk afdeling 3). Die afleiding van die sin onderliggend aan $(40 \mathrm{a} / \mathrm{b})$ kan saamgevat word in die volgende stappe; dié samevatting inkorporeer die werkshipoteses in (31) en (32).

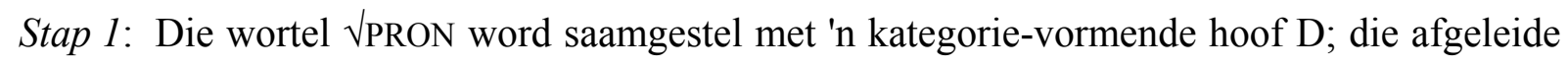
D vorm op sy beurt die hoof van 'n DP. Die afgeleide D, asook die DP waarvan dit die hoof is, het 'n ongewaardeerde K-kenmerk en ongewaardeerde $\varphi$-kenmerke.

Stap 2: Die DP wat tot stand gekom het in stap 1, word (as objek/komplement) saamgestel met die werkwoord verset. Die VP met verset as hoof word daarna saamgestel met 'n klein-v, wat beskik oor 'n gewaardeerde K-kenmerk en ongewaardeerde $\varphi$-kenmerke. Die klein- $v$ tree in 'n soeker-teiken-verhouding met die objek-DP. In die proses word die DP se K-kenmerk gewaardeer as akkusatief. Verder word 'n $\varphi$-ketting gevorm tussen die klein- $v$ en die objekDP. In dié ketting, wat vir die doeleindes van kenmerkwaardering 'n enkele sintaktiese objek verteenwoordig, is die klein- $v$ en die objek-DP se $\varphi$-kenmerke ongewaardeer, wat beteken dat beide elemente steeds aktief is.

Stap 3: Die subjek-DP word in die spesifiseerderposisie van die $v \mathrm{P}$ saamgestel. Die struktuur van hierdie DP is grootliks dieselfde as die struktuur in (13)/(34): die hoof van die DP is

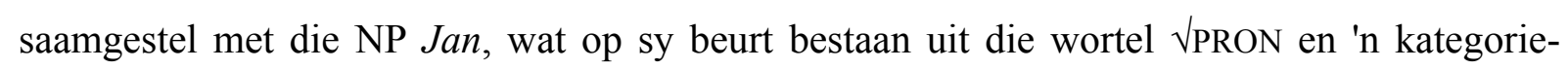
vormende hoof N. Sowel die NP as die DP het gewaardeerde $\varphi$-kenmerke en 'n ongewaardeerde K-kenmerk. Die subjek-DP tree nou in 'n soeker-teiken-verhouding met die klein- $v$. Dit het tot gevolg dat die klein- $v$ se $\varphi$-kenmerke van waardes voorsien word; in die proses word die objek-DP se $\varphi$-kenmerke ook gewaardeer omdat hulle 'n ketting vorm met dié van die klein-v (kyk stap 2). Die klein- $v$ en die objek-DP is dus nou albei onaktief. 
Stap 4: Die uitgebreide $v \mathrm{P}$ wat gevorm is in stap 3, word saamgestel met ' $\mathrm{n} \mathrm{T}$, wat beskik oor 'n gewaardeerde K-kenmerk en ongewaardeerde $\varphi$-kenmerke. Die T tree in 'n soeker-teikenverhouding met die subjek-DP. Dit lei daartoe (i) dat die T se $\varphi$-kenmerke gewaardeer word deur die subjek-DP en (ii) dat die subjek-DP se K-kenmerk (asook dié van sy NP-onderdeel Jan) gewaardeer word as nominatief, wat beteken dat die subjek-DP nou ook onaktief is.

Stap 5: Die T se rand-kenmerk aktiveer die interne saamstel van die subjek-DP in die T se spesifiseerderposisie. Dié bewerking word gevolg deur die saamstel van die TP met 'n C, wat 'n struktuur lewer met dieselfde vorm as die een in (26).

Die afleiding van die sinne onderliggend aan die uitings in (40a) en (40b) vind op wesenlik dieselfde manier plaas. Dit is nie duidelik presies hoe die verskil tussen dié uitings, naamlik die gebruik van 'n komplekse teenoor 'n simplekse vorm van die anafoor, verantwoord kan word in die grammatika nie. Een moontlikheid is dat daar in die afleiding van die objek-DP in (40a) 'n addisionele stap is: die saamstel van 'n soort fokusmerker (kyk voetnoot 50) met die afgeleide D, 'n element wat in die fonologiese komponent gerealiseer word as -self. 'n Ander moontlikheid is dat die betrokke morfofonologiese meganisme gewoon die opsie het om die refleksiewe anafoor foneties uit te spel as 'n akkusatiewe voornaamwoord op sy eie of as 'n komplekse self-vorm. Dié twee moontlikhede, wat klaarblyklik saamhang met dialektiese variasie, word nie verder hier bespreek nie.

Afgesien van die algemene probleme wat in afdeling 4 uitgewys is, bied Heinat $(2005,2006 \mathrm{a}$, 2006b) se voorstelle 'n oënskynlik toereikende raamwerk vir die beskrywing van die verpligte koreferensiële verhouding tussen die subjek en die objek in sinne soos dié onderliggend aan (40a,b), dit wil sê, sinne met 'n oorganklike werkwoord wat uitsluitlik refleksief is. Daar is egter 'n belangrike punt wat in dié verband genoem moet word. Volgens die karakterisering hierbo, het die werkwoorde onder bespreking die eienskap dat hulle verplig 'n refleksiewe anafoor as objek selekteer. Die vraag is nou hoe die sintaktiese meganisme wat betrokke is by die saamstel van die werkwoord en sy objek-DP, "weet" dat 'n gegewe DP 'n refleksiewe anafoor is. Let op dat inligting oor die DP se antesedent nie 'n rol speel by seleksie nie; op die stadium dat die werkwoord en die DP saamgestel word, vorm die DP se antesedent in elk geval nog nie deel van die sinstruktuur nie. Al inligting wat benodig word, is of die DP 'n anafoor is of nie. ${ }^{52}$ In die lig van Chomsky (2005a: 14) se stellings in (38), moet dié inligting 
optimaal vervat wees in 'n enkele element, hier die DP-etiket. In Heinat se analise word 'n refleksief gedefinieer as 'n DP met (aanvanklik) ongewaardeerde $\varphi$-kenmerke (kyk (19)/(35) hierbo). In die geval van uitsluitlik refleksiewe oorganklike werkwoorde, sou die seleksie van 'n objek dus bloot kon inhou die identifisering van 'n DP met ongewaardeerde $\varphi$-kenmerke, inligting wat vervat is in die DP-etiket en wat met minimale verwerkingskoste bekom kan word vir die saamstelbewerking. Anders gestel, die seleksie van 'n refleksiewe anafoor sou gelyk gestel kon word aan die seleksie van 'n DP met die kenmerk [o甲]].

Hierdie voorstel in verband met die seleksie van 'n anaforiese objek blyk versoenbaar te wees met Heinat se analise. Trouens, as seleksie nie "gevoelig" is vir 'n DP se kenmerke nie, is dit onduidelik - gegee die stellings oor verwerkingskoste in (38) - hoe die seleksie-eienskap van uitsluitlik refleksiewe werkwoorde binne sy analise verantwoord kan word. Juis daarom is dit vreemd dat Heinat (2006a: 36-7) die idee dat DP's se grammatikale kenmerke 'n rol speel by seleksie, uitdruklik verwerp, sonder om 'n alternatiewe voorstel te maak oor hoe 'n anaforiese DP formeel geïdentifiseer kan word vir seleksie-doeleindes. Hy (2006a: 37) maak byvoorbeeld die volgende opmerkings met verwysing na grammatikale geslag (een van die $\varphi$ kenmerke):

(41) ... (most) verbs do not make a selectional difference between DPs of different genders, but they do make a difference between DPs and for example, CPs in selection; DPS are selected because they are DPs [my kursivering - JO].

Beskou vervolgens die uitings in (42)-(44). Hierdie uitings illustreer 'n tweede tipe verplig refleksiewe konstruksie in Afrikaans, een wat informeel beskryf kan word as 'n "faktitiewe (of resultatiewe) refleksiewe konstruksie".

(42) a. $\operatorname{Jan}_{\mathrm{i}}$ drink hom(self) $)_{\mathrm{i}}$ bewusteloos.

b. $\quad * \operatorname{Jan}_{\mathrm{i}}$ drink hom $\mathrm{j}_{\mathrm{j}}$ bewusteloos.

c. $\quad * \operatorname{Jan}_{\mathrm{i}}$ drink hom(self) $)_{\mathrm{i}}$.

d. $\quad * J_{a n}$ drink bewusteloos.

(43) a. Hy $y_{i}$ hou hom(self) ${ }_{i}$ 'n kenner.

b. $\quad * \mathrm{Hy}_{\mathrm{i}}$ hou hom $\mathrm{j}_{\mathrm{j}} \mathrm{n}$ kenner.

c. $\quad * \mathrm{Hy}_{\mathrm{i}}$ hou hom(self) $)_{\mathrm{i}}$.

d. $*$ Hy hou 'n kenner. 

a. Marie $_{i}$ skrik haar(self) $)_{i}$ in 'n koma.
b. * Marie skrik haar $_{\mathrm{j}}$ in 'n koma.
c. * Marie $\mathrm{i}_{\mathrm{i}}$ skrik haar(self) .
d. $*$ Marie $_{i}$ skrik in 'n koma.

Die werkwoorde in die (a)-uitings word almal faktitief gebruik, waarmee bedoel word dat die subjek se referent (die agent Jan/hy, die ervaarder Marie) in 'n sekere toestand verkeer of gebring word as gevolg van die handeling of gebeurtenis wat deur die werkwoord aangedui word. In (42a) bring die handeling van "drink" byvoorbeeld vir Jan in die toestand van "bewusteloosheid". Die werkwoord kan onoorganklik wees (soos hou in (43a) en skrik in (44a)), of dit kan een wees met die eienskap dat dit opsioneel oorganklik is (soos drink in (42a)). ${ }^{53}$ Die komplement van die werkwoord bestaan uit twee elemente, naamlik (i) 'n refleksief wat koreferensieel is met die subjek ${ }^{54}$ en (ii) 'n uitdrukking wat die betrokke toestand aandui; dié elemente is sowel afsonderlik as gesamentlik verplig, soos blyk uit die onaanvaarbaarheid van die (b-d)-uitings in (42)-(44). Verder is die element wat die toestand aandui, nie beperk tot 'n spesifieke sintaktiese kategorie nie: in (42a) is dit 'n adjektiwiese frase (AP, bewusteloos), in (43a) 'n nominale frase (DP, 'n kenner) en in (44a) 'n preposisionele frase (PP, in 'n koma).

Die refleksief in faktitiewe refleksiewe konstruksies funksioneer nie as die objek van die werkwoord nie, maar eerder as die subjek van die element wat die toestand aandui. In (42a), byvoorbeeld, is hom nie 'n argument van die werkwoord drink nie, maar van die AP bewusteloos - die toestand van "bewusteloosheid" word gepredikeer van die refleksief hom, die ervaarder van die toestand. Die refleksief se antesedent, die subjek-DP Jan, word op sy beurt geïnterpreteer as die agent van die handeling wat aangedui word deur drink. Kortom, die elementreeks [refleksief-AP/DP/PP] in faktitiewe refleksiewe konstruksies druk, net soos volledige sinne, 'n proposisionele betekenis uit; anders as volledige sinne, egter, besit dit nie werkwoordelike elemente nie. Sulke elementreekse staan bekend as "beknopte sinne" ("small clauses" of "verbless clauses"). ${ }^{55}$

Vir die doeleindes van die artikel word aangeneem dat beknopte sinne die algemene struktuur in (44) het, waar F 'n funksionele hoof verteenwoordig en XP die predikatiewe uitdrukking is 
wat die betrokke toestand aandui ('n AP, DP of PP). In dié struktuur vorm die refleksief-DP en die XP onderskeidelik die spesifiseerder en die komplement van die $\mathrm{F}^{56}$

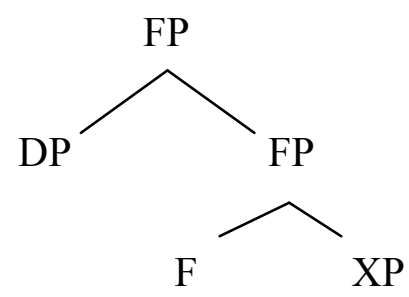

Heinat $(2005 ; 2006 a ; 2006 b)$ gee nie aandag aan faktitiewe refleksiewe konstruksies nie. Die vraag is nietemin of sy voorstelle in afdeling 3 wel 'n basis kan bied vir die beskrywing van die referensiële verhoudings in hierdie soort konstruksie. Beskou byvoorbeeld die uiting in (42a). Binne Heinat se raamwerk sou die afleiding van die sin onderliggend aan hierdie uiting stapsgewys soos hieronder beskryf kan word; dié beskrywing maak gebruik van die werkshipoteses in (31) en (32) en die struktuur in (44). Vir die doel van die bespreking word twee verdere aannames in verband met (44) gemaak: (i) die AP het 'n ongewaardeerde K-kenmerk asook ongewaardeerde $\varphi$-kenmerke, en (ii) die F het ongewaardeerde $\varphi$-kenmerke maar nie 'n K-kenmerk nie. ${ }^{57}$

Stap 1: Die kategorie F word saamgestel met die AP bewusteloos. ${ }^{58}$ Dié twee elemente tree in 'n soeker-teiken-verhouding met mekaar, maar omdat albei se $\varphi$-kenmerke ongewaardeer is, hou kongruensie bloot in dat 'n ketting gevorm word waarin die twee stelle $\varphi$-kenmerke dieselfde "geen-waarde" deel, aangedui deur [2] in die struktuur hieronder. Omdat die F nie 'n K-kenmerk het nie, kan dié van die AP nie gewaardeer word nie. Die F en die AP bly dus albei aktief. $^{59}$

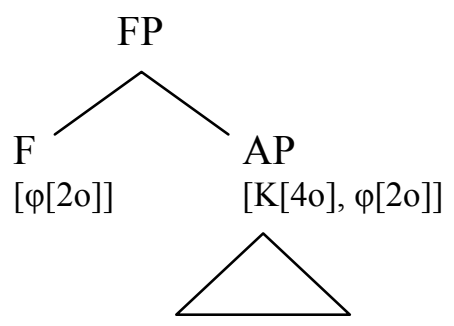

bewusteloos 
Stap 2: Die refleksief, met die struktuur in (19), word saamgestel in die spesifiseerderposisie van die F. Die resultaat is 'n beknopte sin met die struktuur in (46). Die refleksief tree in 'n kongruensie-verhouding met die teikens in sy k-kommandeer-domein - die F(P) en die AP maar sy kenmerke kan nie gewaardeer word deur dié elemente nie. 'n K-ketting word wel gevorm tussen die refleksief en die AP (aangedui deur [4] in (46)), en 'n $\varphi$-ketting (aangedui deur [2]) tussen die refleksief en die F(P) (en dus ook die AP omdat dié reeds in 'n $\varphi$-ketting met die F is). Die betrokke elemente is steeds almal aktief.

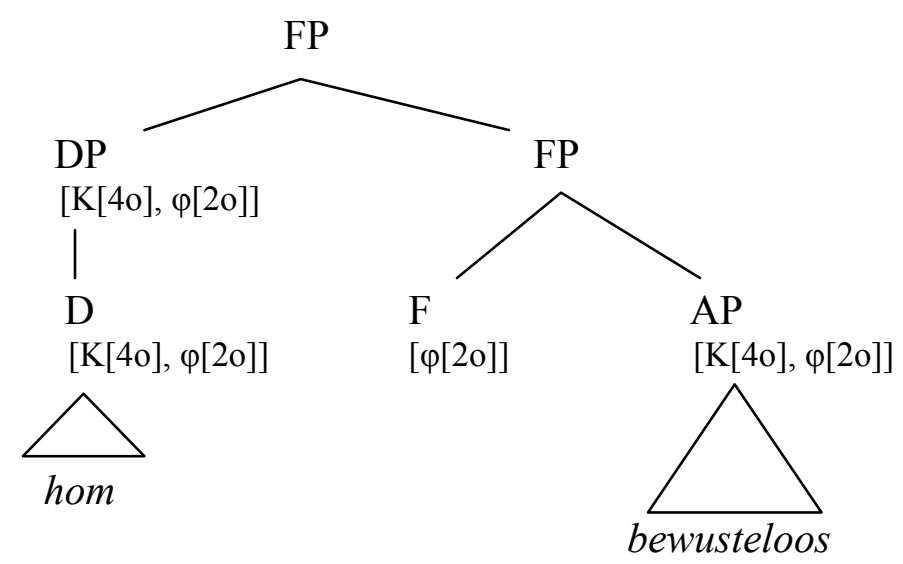

Stap 3: Die FP word saamgestel met die V drink om 'n VP te vorm. Dit word gevolg deur die saamstel van die VP met 'n klein- $v$, wat 'n gewaardeerde K-kenmerk en ongewaardeerde $\varphi$ kenmerke besit. Die klein- $v$ tree in 'n kongruensie-verhouding met die verskillende teikens in sy k-kommandeer-domein (die F(P), die refleksief-DP en die AP). Dit bring mee dat die DP en die AP se K-kenmerke - wat 'n ketting vorm - dieselfde waarde vanaf die klein- $v$ kry, naamlik akkusatief, aangedui deur [3] in die struktuur (47). Die klein- $v$ se $\varphi$-kenmerke kan nie van waardes voorsien word deur enige van die teiken-elemente nie. 'n $\varphi$-Ketting word egter gevorm tussen die klein- $v$ en die $\mathrm{F}$ (en by implikasie tussen die klein- $v$ en die ander teikens in sy domein, gegee die $\varphi$-kettings wat reeds in stappe 1 en 2 gevorm is). 
(47)

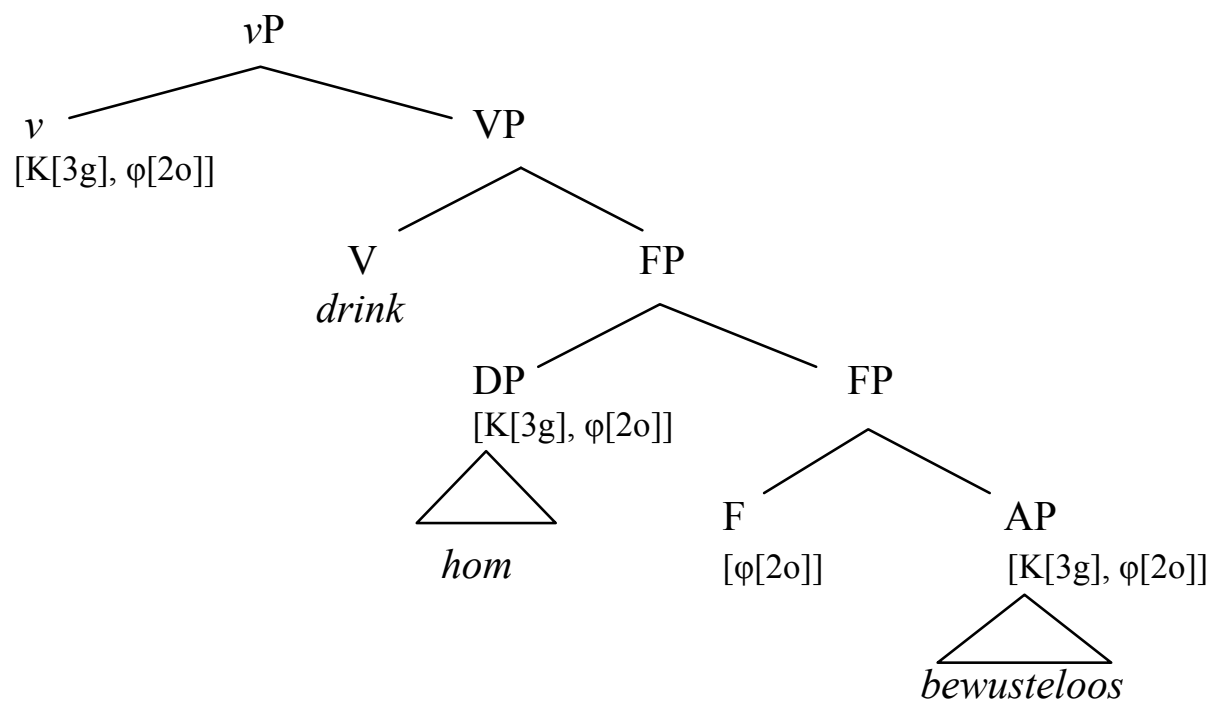

Stap 4: Die subjek-DP, met die struktuur in (13), word saamgestel in die spesifiseerderposisie van die klein- $v$. Beide die DP en sy onderdeel, die NP Jan, het 'n ongewaardeerde K-kenmerk en gewaardeerde $\varphi$-kenmerke. Die DP tree in 'n kongruensie-verhouding met die teikens in sy k-kommandeer-domein, naamlik die klein- $v(\mathrm{P})$, die F(P), die refleksief-DP en die AP. Dit lei daartoe dat dié teikens se $\varphi$-kenmerke - wat deel vorm van dieselfde uitgebreide $\varphi$-ketting gewaardeer word deur die subjek-DP se $\varphi$-kenmerk, aangedui deur [5] in die struktuur (48). In die proses word die klein- $v(\mathrm{P})$, die $\mathrm{F}(\mathrm{P})$, die refleksief-DP en die AP onaktief. Die subjek-DP word nie k-kommandeer deur die klein-v nie, wat beteken dat sy K-kenmerk, asook dié van die NP Jan, ongewaardeer bly. Die subjek-DP en sy NP-onderdeel is dus albei nog aktief.

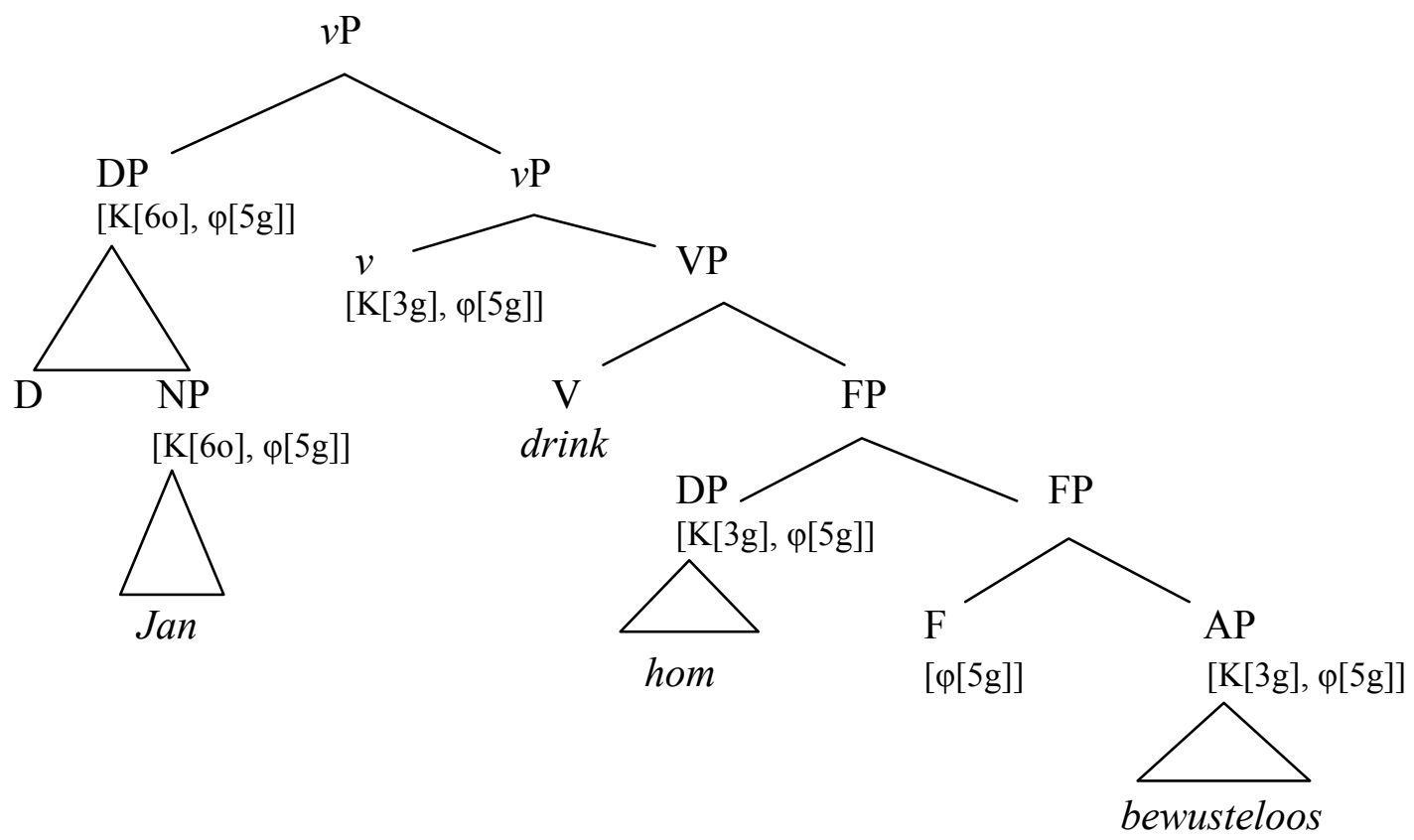


Stap 5: Die $v \mathrm{P}$ word saamgestel met 'n $\mathrm{T}$, wat beskik oor 'n rand-kenmerk, 'n gewaardeerde K-kenmerk en ongewaardeerde $\varphi$-kenmerke. Die $\mathrm{T}$ tree in 'n soeker-teiken-verhouding met die subjek-DP, wat tot gevolg het dat sy $\varphi$-kenmerke deur dié van die DP gewaardeer word (aangedui deur [5] in die struktuur hieronder). Verder word die DP en die NP se K-kenmerk as nominatief gewaardeer deur dié van die T (aangedui deur [7]). Al drie die elemente is nou onaktief vanuit 'n soeker-teiken-oogpunt. Die T se rand-kenmerk bring vervolgens mee dat die subjek-DP intern saamgestel word in die $\mathrm{T}$ se spesifiseerderposisie. Hierdie bewerking word gevolg deur die saamstel van die TP met 'n C. Die uiteindelike struktuur kan soos volg voorgestel word:

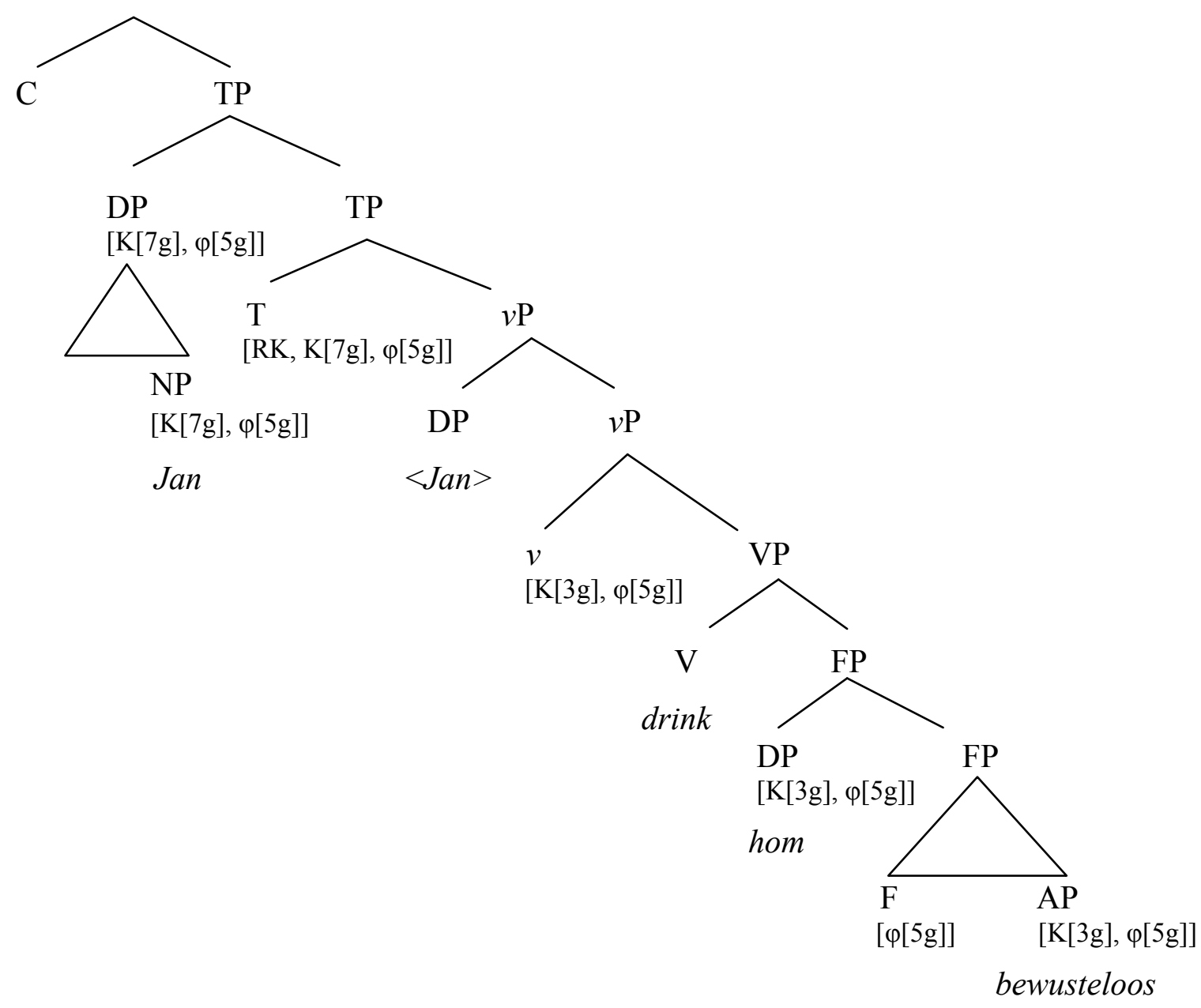

Al die K- en $\varphi$-kenmerke in (49) is gewaardeer. Wat egter hier belangrik is, is die feit dat die refleksief sy $\varphi$-kenmerkwaardes verkry het in 'n soeker-teiken-verhouding met die subjek-DP. Binne Heinat se raamwerk is dit genoegsame gronde vir die vaslegging van 'n koreferensiële 
verhouding tussen hierdie twee elemente. Sy voorstelle bied dus oënskynlik 'n toereikende basis vir die beskrywing van die feit dat die refleksief in 'n Afrikaanse faktitiewe refleksiewe konstruksie verplig koreferensieel is met die subjek. In dié verband moet egter gelet word op 'n potensiële probleem in die geval van uitings soos die een in (43a) Hy hou hom $_{i}$ 'n kenner. ${ }^{60}$ Die afleiding van die beknopte sin hom 'n kenner in dié voorbeeld kan in Heinat se raamwerk voorgestel word in die volgende stappe.

Stap 1: Die funksionele hoof $\mathrm{F}$ word saamgestel met die DP 'n kenner, 'n r-uitdrukking, wat opgebou is uit 'n D ' $n$ en 'n NP met die N kenner as hoof. ${ }^{61}$ Die D en die NP het albei 'n Kkenmerk en $\varphi$-kenmerke. Die NP se K-kenmerk is ongewaardeer, maar sy $\varphi$-kenmerke het spesifieke waardes; daarteenoor is die D se kenmerke aanvanklik almal ongewaardeer. Die D tree in 'n kongruensie-verhouding met die NP, wat meebring dat sy $\varphi$-kenmerke gewaardeer word (aangedui as [5] in die struktuur hieronder); dié $\varphi$-kenmerkwaardes is ook vervat in die DP-etiket. Die F besit nie 'n K-kenmerk nie, maar wel ongewaardeerde $\varphi$-kenmerke wat in kongruensie met die $\mathrm{D}(\mathrm{P})$ (of die NP) van waardes voorsien word.

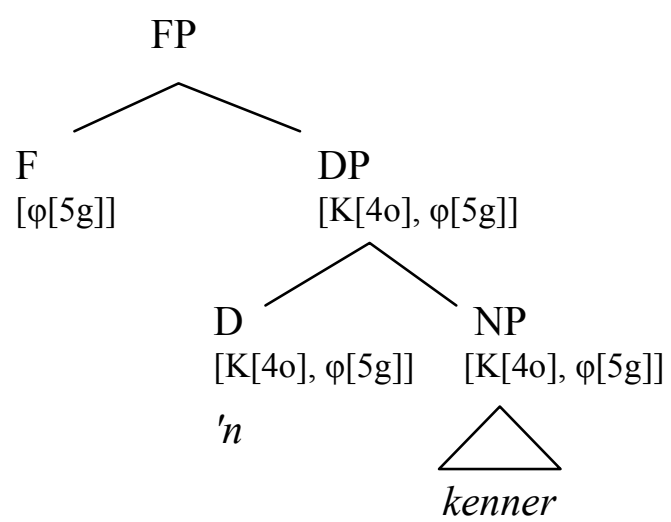

Stap 2: Die refleksief-DP hom, met die interne struktuur in (19), word saamgestel in die spesifiseerderposisie van die F. Die refleksief kom die afleiding binne met ongewaardeerde $\mathrm{K}$ - en $\varphi$-kenmerke. As 'n soeker tree dit vervolgens in 'n kongruensie-verhouding met die DP 'n kenner (en sy onderdele, die D en die NP), wat beskik oor gewaardeerde $\varphi$-kenmerke. Die gevolg is dat die refleksief se $\varphi$-kenmerke voorsien word van spesifieke waardes, aangedui deur [5] in die onderstaande struktuur. Die refleksief vorm verder 'n K-ketting met die predikatiewe DP, aangedui deur [4]; die kenmerke in dié ketting bly egter ongewaardeer. 


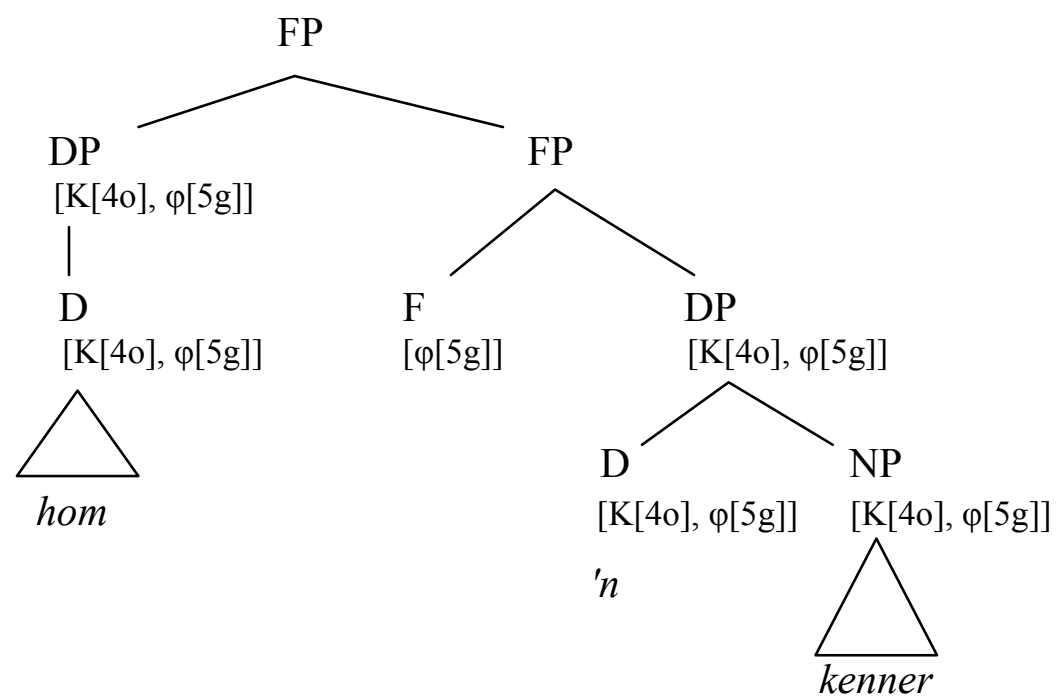

Die probleem met hierdie beskrywing is dat die refleksief se $\varphi$-kenmerke reeds gewaardeer is wanneer die subjek-DP Jan op 'n later stadium in die struktuur saamgestel word. Omdat die refleksief nie sy $\varphi$-kenmerkwaardes verkry in 'n soeker-teiken-verhouding met die subjek-DP nie, is daar dus binne Heinat se raamwerk klaarblyklik geen gronde vir die vaslegging van 'n koreferensiële verhouding tussen hierdie twee elemente nie. Gegee die bostaande beskrywing, sou daar dus verkeerdelik voorspel word dat 'n uiting soos (43a) aanvaarbaar is met 'n niekoreferensiële verhouding tussen die refleksief en die subjek; of anders gestel, dat so 'n uiting onaanvaarbaar is met 'n koreferensiële verhouding tussen die refleksief en die subjek.

\section{Samevatting en gevolgtrekking}

In hierdie artikel is daar krities gekyk na Heinat (2005, 2006a, 2006b) se onlangse minimalistiese analise van die (ko)referensiële verhoudings waarby refleksiewe anafore enersyds en voornaamwoorde andersyds betrokke is. Die bespreking is gerig deur twee vrae waarop enige toereikende analise van die referensiële verhoudings tussen nominale uitdrukkings antwoorde moet gee; dié vrae, geformuleer as (2) en (3), word geriefshalwe hier herhaal.

(2) Met watter middele kan die onderskeiding tussen anafore, voornaamwoorde en ruitdrukkings beskryf word?

(3) Met watter middele kan die vaslegging van 'n koreferensiële verhouding tussen 'n anafoor - spesifiek, 'n refleksief - en sy antesedent verklaar word? 
Heinat bied sy analise aan as 'n alternatief vir die GB-Bindingsteorie; as agtergrond is daar in afdeling 2 'n kort uiteensetting gegee van die vernaamste konsepte van dié teorie. Die sentrale hipoteses en gepaardgaande meganismes van Heinat se analise is uiteengesit en geillustreer in afdeling 3. Die hooftrekke van die analise kan soos volg saamgevat word teen die agtergrond van die vrae in (2) en (3).

\section{(52) Wat betref vraag (2):}

(i) Voornaamwoorde en refleksiewe is samestellings wat uit dieselfde leksikale wortel $\sqrt{ }$ PRON gevorm word. $\sqrt{ }$ PRON word in die loop van 'n afleiding saamgestel met 'n kategorie-vormende hoof, ' $\mathrm{N}$ in die geval van voornaamwoorde en ' $\mathrm{D}$ D in die geval van refleksiewe. 'n Voornaamwoord is dus 'n afgeleide $\mathrm{N}$ en 'n refleksief 'n afgeleide D. Die onderskeiding tussen voornaamwoorde en refleksiewe word met ander woorde bepaal deur die kategorie van die hoof waarmee $\sqrt{ }$ PRON saamgestel word, nie deur leksikale kenmerke soos [pronominaal] en [anafoor] nie. Die morfofonologiese vorm van 'n spesifieke voornaamwoord of refleksief word bepaal deur die meganismes van die fonologiese komponent.

(ii) $\mathrm{N}$ en $\mathrm{D}$ het albei ' $\mathrm{N}$ K-kenmerk en $\varphi$-kenmerke. ' $\mathrm{n} \mathrm{N}$ se K-kenmerk is ongewaardeer, maar sy $\varphi$-kenmerke het spesifieke waardes; ' $\mathrm{D}$ D se kenmerke is almal ongewaardeer. Dié verskil in $\varphi$-waardes beteken aan die een kant dat 'n voornaamwoord - 'n afgeleide $\mathrm{N}$ - nie afhanklik is van ' $\mathrm{n}$ ander element om sy $\varphi$-kenmerke te waardeer nie; ' $\mathrm{n}$ voornaamwoord kan dus op sy eie gebruik word om na 'n referent te verwys. Aan die ander kant is 'n refleksief - 'n afgeleide D - wel afhanklik van 'n ander element om hom van $\varphi$-kenmerkwaardes te voorsien. Hierdie afhanklikheid lê ten grondslag daarvan dat refleksiewe geïnterpreteer word as anaforiese uitdrukkings: 'n refleksief kan sy verwysing slegs verkry deur 'n antesedent waarmee hy in 'n $\varphi$-kongruensie-verhouding tree.

(53) Wat betref vraag (3):

(i) 'n Uitdrukking A is koreferensieel met 'n uitdrukking B indien die $\varphi$-kenmerke van A gewaardeer word deur dié van B in 'n soeker-teiken-verhouding. Anders gestel, koreferensie korrespondeer met soeker-teiken-geïnduseerde $\varphi$-kongruensie.

(ii) Om in 'n soeker-teiken-verhouding te kan tree, moet die betrokke elemente elkeen ten minste een ongewaardeerde kenmerk bevat; verder moet die soeker die teiken k- 
kommandeer. Nie net hoofde nie, maar ook frases kan optree as soekers. Dit beteken dat twee DP's in 'n soeker-teiken-verhouding kan staan waar die teiken-DP se $\varphi$ kenmerke gewaardeer word deur dié van die soeker-DP; dit is juis op hierdie manier wat die koreferensiële verhouding tussen 'n refleksiewe teiken-DP en sy antesedent vasgelê word.

In afdeling 4 is aandag gegee aan enkele algemene kwessies wat potensieel problematies is vir Heinat se analise. Die vernaamste bevindings word hieronder saamgevat.

\section{Wat betref K-kenmerkwaardering:}

(i) In die afleiding van 'n sin soos Jan haat homself verkry die subjek twee verskillende K-kenmerkwaardes: akkusatief vanaf die klein- $v$ en nominatief vanaf die T. Die toekenning van akkusatiewe kasus is strydig met die feit dat die subjek-DP van 'n finiete sin nominatiewe kasus vertoon.

(ii) Op die stadium dat die $\mathrm{T}$ in die afleiding saamgestel word, besit die subjek-DP self geen ongewaardeerde kenmerke nie, wat beteken dat dit onaktief is vanuit die oogpunt van soeker-teiken-verhoudings. Om voorsiening te maak daarvoor dat die subjek wel nominatiewe kasus van die T kan ontvang, stel Heinat voor dat die DP steeds aktief is omdat dit 'n aktiewe NP as onderdeel bevat. Dié voorstel is strydig met die algemene aanname dat slegs elemente met 'n ongewaardeerde kenmerk kan optree as teikens (of soekers). Verder is dit onduidelik hoe die idee dat 'n element aktief kan bly nadat al sy kenmerke reeds gewaardeer is, formeel aangedui kan word.

(iii) Heinat meld twee alternatiewe benaderings ten opsigte van die subjek se ongewenste akkusatiewe kasus. Die eerste is om aan te neem dat die T 'n "sterk" ("strong") nominatiewe K-waarde het wat die subjek-DP se akkusatiewe K-waarde "uitknikker" ("knocks out"). Dit is egter nie duidelik wat bedoel word met die uitdrukkings "strong" en "knocks out" nie, en ook nie hoe die inhoud van elkeen formeel uitgedruk kan word in die grammatika nie. Verder is dit onduidelik waarom die objek-DP se akkusatiewe K-waarde nie ook "uitgeknikker" word deur die T se "sterk" nominatiewe waarde nie. Sonder 'n (behoorlik gemotiveerde) beperking in dié verband sal die objek-DP verkeerdelik eindig met nominatiewe kasus. 
Die tweede benadering is gebaseer op die algemene idee dat 'n semanties-oninterpreteerbare kenmerk (byvoorbeeld 'n DP se K-kenmerk) geskrap word wanneer die betrokke fase na die semantiese komponent toe oorgedra word, mits die kenmerk gewaardeer is. Dit maak dus nie saak as die kenmerk meer as een waarde (byvoorbeeld akkusatief én nominatief) ontvang nie, want dit speel geen semantiese rol nie. Die probleem is egter dat DP's se K-kenmerke wel foneties-interpreteerbaar is en derhalwe nie geskrap word tydens oordrag na die fonologiese komponent toe nie. 'n DP met meer as een K-kenmerkwaarde sal duidelik problematies wees vir die meganismes wat 'n rol speel by die bepaling van morfofonologiese vorm.

Wat betref $\varphi$-kenmerkwaardering:

Binne Heinat se analise is twee DP's met identiese $\varphi$-waardes slegs koreferensieel as hulle dié waardes in 'n soeker-teiken-verhouding deel. Die probleem is egter dat daar op die stadium van oordrag na die semantiese komponent toe geen formele aanduiding is of ' $\mathrm{D}$ DP sy $\varphi$ waardes DP-intern of in 'n kongruensie-verhouding met 'n soeker-DP verkry het nie. Sonder so ' $\mathrm{n}$ aanduiding is daar duidelik nie ' $\mathrm{n}$ basis vir die interpretasie van die betrokke DP as ' $\mathrm{n}$ refleksiewe anafoor en die soeker-DP as sy antesedent nie.

In afdeling 5 is nagegaan of Heinat se voorstelle 'n toereikende raamwerk bied vir die beskrywing van die referensiële verhoudings in twee tipes verplig refleksiewe konstruksies in Afrikaans: konstruksies met uitsluitlik refleksiewe werkwoorde en faktitiewe refleksiewe konstruksies. In die loop van die bespreking is daar gewys op die volgende twee potensieel problematiese aspekte.

Wat betref konstruksies met uitsluitlik refleksiewe werkwoorde:

Dit is nie duidelik hoe die sintaktiese meganisme wat betrokke is by die saamstel van ' $n$ verplig refleksiewe werkwoord (soos verset) en sy objek-DP, "weet" dat 'n gegewe DP 'n refleksiewe anafoor is nie. Binne Heinat se raamwerk word 'n refleksief gedefinieer as ' $n$ DP met (aanvanklik) ongewaardeerde $\varphi$-kenmerke. 'n Moontlikheid is dus dat seleksie in die geval van verplig refleksiewe werkwoorde gewoon inhou die identifisering van 'n DP met die kenmerk $[o \varphi]$. Heinat verwerp egter die idee dat seleksie "gevoelig" is vir die $\varphi$-kenmerke van DP's, sonder om 'n alternatiewe voorstel te maak oor hoe 'n refleksiewe anafoor formeel geïdentifiseer kan word vir seleksie-doeleindes. 
Wat betreffaktitiewe refleksiewe konstruksies:

Binne Heinat se raamwerk word die $\varphi$-kenmerke van die refleksief in 'n beknopte sin soos in Jan hou [hom 'n kenner] gewaardeer deur die predikatiewe DP; met ander woorde, hom kry sy $\varphi$-waardes in 'n soeker-teiken-verhouding vanaf die DP ' $n$ kenner, nie vanaf die sin se subjek-DP Jan nie. Omdat die refleksief nie sy $\varphi$-waardes in 'n soeker-teiken-verhouding met die subjek ontvang nie, is daar klaarblyklik geen basis vir die vaslegging van 'n koreferensiële verhouding tussen dié twee elemente nie. Binne Heinat se raamwerk word dus verkeerdelik voorspel dat die refleksief in 'n uiting soos Jan hou hom 'n kenner nie-koreferensieel is met die subjek Jan.

Die probleme wat saamgevat is in (54)-(57) plaas duidelik 'n ernstige vraagteken oor die meriete van Heinat se voorstelle, uit sowel 'n algemeen-teoretiese oogpunt as die oogpunt van die Afrikaanse grammatika.

In die lig van die beperkte oogmerke van hierdie artikel, is verskeie potensieel interessante kwessies bewustelik buite rekening gelaat. Ter afsluiting word twee van dié kwessies hier kortliks genoem. Die eerste het 'n algemeen-teoretiese strekking. 'n Sleutelkonsep in sowel Heinat se analise as die GB-Bindingsteorie is dié van k-kommandeer, weergegee as (5) in afdeling 2 . In beide benaderings moet ' $n$ anafoor k-kommandeer word deur sy antesedent, ongeag met watter middele die koreferensiële verhouding tussen die twee elemente vasgelê word. Beskou egter in dié verband die volgende opmerkings van Chomsky (2005b: 8):

(58) We therefore have two syntactic relations: (A) set-membership, based on Merge, and (B) probe-goal relations. Assuming composition of relations, (A) yields the notions term-of and dominate. These seem to be the minimal assumptions about the available relations. If we add "sister-of," then composition will yield c-command and identity (the latter presumably available independently). Whether c-command plays a role within the computation to the C-I interface is an open question. I know of no clear evidence that it does, so will keep to the relations that seem unavoidable, setmembership and probe-goal.

Indien voldoende onafhanklike gronde gevind kan word vir die eliminasie van k-kommandeer as 'n basiese sintaktiese verhouding, sal dit uiteraard ernstige implikasies hê vir enige analise van (ko)referensiële verhoudings waarin k-kommandeer 'n sleutelrol speel. Zwart (2002) se analise is 'n interessante poging om vraag (3) hierbo te beantwoord sonder om gebruik te 
maak van die konsep k-kommandeer. 'n Bespreking van Zwart se analise val egter buite die bereik van hierdie artikel. ${ }^{62}$

Die tweede kwessie betref die konstruksies in Afrikaans wat as "verplig refleksief" beskryf kan word. Benewens die twee wat in afdeling 5 bespreek is, bevat Afrikaans ten minste ook nog dié geïllustreer deur die voorbeelde in (59)-(62).

(59) Refleksief as die objek van 'n preposisie: ${ }^{63}$
a. $\quad \operatorname{Jan}_{\mathrm{i}}$ glimlag (dink, sug, prewel) [by homself $\mathrm{i}_{\mathrm{i}}$ (is buite homself van woede).
b. $\quad * J \operatorname{Jan}_{\mathrm{i}}$ glimlag (dink, sug, prewel) [by hom $\mathrm{i}$.
c. * $\quad \operatorname{Jan}_{\mathrm{i}}$ glimlag (dink, sug, prewel) [by hom $\left.{ }_{\mathrm{j}}\right]$.

(60) Refleksief as die subjek van 'n "persoonsdeel-besitskonstruksie" wat funksioneer as die objek van 'n werkwoord: ${ }^{64}$
a. $\quad$ Marie $_{i}$ knip [haar ${ }_{i}$ ö̈] (spits haar ore, blaas haar asem uit).

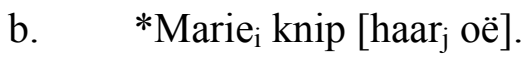

(61) Refleksief as die subjek van 'n "persoonsdeel-besitskonstruksie" wat funksioneer as die objek van 'n preposisie:
a. Marie $_{\mathrm{i}}$ het die nuus [in haar ${ }_{\mathrm{i}}$ hart] bewaar (die huis in haar gedagtes gesien, die kinders met haar lewe beskerm, uit haar maag gelag).
b. $\quad *$ Marie $_{i}$ het die nuus [in haar ${ }_{j}$ hart] bewaar.

(62) Refleksief as die subjek van 'n "persoonsdeel-besitskonstruksie" wat funksioneer as die objek van 'n preposisie (waar die refleksief voorkom saam met die element eie):
a. $\quad \operatorname{Jan}_{\mathrm{i}}$ het dit [met sy $\mathrm{i}_{\mathrm{i}}$ eie ö̈] gesien (van sy eie gesondheid gesê, na sy eie smaak ingerig, vir sy eie plesier gedoen).
b. $\quad * J_{a n}$ het dit $\left[\right.$ met $s_{j}$ eie oë] gesien.

'n Toereikende analise van die referensiële verhoudings waarin uitdrukkings kan tree, moet uiteraard ook die verhoudings in die bostaande verplig refleksiewe konstruksies kan beskryf. So 'n beskrywing en die talle ander kwessies wat in die loop van die artikel uitgewys is, word gelaat as onderwerpe vir verdere ondersoek. 


\section{Notas}

* Ek bedank graag vir Walter Winckler vir sy waardevolle bydraes, inhoudelik en redaksioneel. Dank ook aan Theresa Biberauer vir haar insiggewende kommentaar op 'n vroeëre weergawe van hierdie artikel. Enige misverstande, wanvoorstellings en ander gebreke is egter vir my eie rekening.

1. Die volgende idee lê ten grondslag van die gebruik van die terme "referensie"/"verwysing" en die verwante terme "koreferensie" en "(ko)referensiële verhouding" in hierdie artikel: taalgebruikers gebruik uitings van taaleenhede om te verwys na sake in die werklikheid oftewel referente, waar met "sake in die werklikheid"/ "referente" bedoel word: sake in 'n taalgebruiker se gekonseptualiseerde werklikheid, hetsy gekonseptualiseer uit sy ervaring of uit sy verbeelding. Die sake waarna verwys word is dus nie onafhanklik van die taalgebruiker se geestesvermoëns nie. Dit beteken dat die verbande wat deur verwysing tot stand kom - die "referensiële verhoudings" - intern aan die taalgebruiker se geestesvermoëns bestaan. Kortom, daar bestaan nie 'n "referensiële verhouding" tussen die eenhede van taal enersyds en 'n wêreld buite en los van die taalgebruiker se geestesvermoëns andersyds nie. Kyk bv. Chomsky (2004b: 388-92) en Smith (1998, 1999: 42-3, 166-7) vir 'n bespreking van die wesenlike onderskeid tussen die bogenoemde idee en die alternatiewe idee dat 'n taaleenheid self na 'n saak buite die taalgebruiker se geestesvermoëns verwys. In hierdie artikel word die stelwyse "'n taaleenheid/uitdrukking verwys" bloot geriefshalwe gebruik vir die meer presiese stelwyse "die taalgebruiker verwys na 'n saak in sy gekonseptualiseerde werklikheid deur middel van 'n uiting van 'n taaleenheid".

2. Kyk bv. Büring (2004); Chomsky (1981, 1982, 1985, 1986); Chomsky en Lasnik (1993, in Chomsky 1995a); Heinat (2005, 2006a, 2006b); Kayne (2002); Reinhart (1983); Reinhart en Reuland (1993); Reuland (2001); Reuland en Everaert (2001); Zwart (2002); en die talle verwysings in hierdie werke.

3. Die terme "refleksief" en "voornaamwoord" word voortaan kortweg gebruik vir onderskeidelik "refleksiewe voornaamwoord" en "persoonlike voornaamwoord".

4. Benewens uitdrukkings met fonetiese inhoud, maak die tipologie ook voorsiening vir nie-overte nominale uitdrukkings, dit wil sê, uitdrukkings wat nie foneties manifesteer nie. Hiervolgens verteenwoordig die spore van NP-skuif nie-overte anafore (kyk (ia) hieronder), die spore van W-Skuif nie-overte r-uitdrukkings (kyk (ib)), en die element pro 'n nie-overte persoonlike voornaamwoord (tipies aangetref in die subjekposisie van finiete sinne in sogenaamde nulsubjektale soos bv. Spaans; kyk (ic)).

(i) a. Marie is genooi $[\mathrm{t}]$ na die partytjie toe.

( $\mathrm{t}$ die spoor van die verskuifde nominale frase Marie)

b. Watter meisie het hy genooi $[\mathrm{t}]$ ?

( $\mathrm{t}$ die spoor van die verskuifde w-frase watter meisie)

c. pro Vimos a Maria. (ons) sien vir Marie (pro die nie-overte ekwiwalent van ons)

Die tipologie voorspel verder die bestaan van 'n uitdrukking met die kenmerke $[+\mathrm{a},+\mathrm{p}]$ : die nie-overte element PRO wat voorkom in die subjekposisie van die infinitiewe komplement van sogenaamde kontrole-werkwoorde (kyk (ii) hieronder). Hoewel PRO deel vorm van die tipologie van nominale uitdrukkings, word die referensiële 
verhoudings waarin dit kan tree nie gereguleer deur die meganismes van Bindingsteorie nie maar deur dié van Kontrole-teorie, 'n afsonderlike subteorie van die grammatika binne die GB-raamwerk.

(ii) a. Jan belowe vir Marie [om PRO saam te gaan]. (subjekkontrole: PRO het dieselfde referent as Jan)

b. Jan nooi vir Marie [om PRO saam te gaan]. (objekkontrole: PRO het dieselfde referent as Marie)

5. Kyk Chomsky (1995a: 100) vir die prosedures vir die interpretasie van voornaamwoorde en r-uitdrukkings. Die prosedure in (4) is 'n aanpassing van Beginsel A van die standaard-Bindingsteorie, dit wil sê, die versie van die teorie wat ontwikkel is in Chomsky $(1981,1982,1985,1986)$. Beginsel A is een van drie beginsels wat betrokke is by die regulering van die referensiële verhoudings waarin nominale uitdrukkings kan tree. Dié beginsels lui soos volg (Chomsky (1982: 20):

Beginsel A: ' $\mathrm{n}$ anafoor is gebind in sy regerende kategorie.

Beginsel B: 'n voornaamwoord is vry in sy regerende kategorie.

Beginsel C: 'n r-uitdrukking is vry.

6. In die standaard-Bindingsteorie (kyk vn. 5), word 'n anafoor A "gekoïndekseer" met 'n uitdrukking B - die antesedent van A - as A se $\varphi$-kenmerke kongrueer met dié van B, konvensioneel aangedui met die voetskrifte i, $j$, ens.; bv. in $\left[\ldots C_{j} \ldots B_{i} \ldots A_{i} \ldots\right]$ kongrueer A met B maar nie met $C$ nie. Met "koïndeksering" word oënskynlik bedoel dat die antesedent se sogenaamde "(referensiële) indeks" toegeken word aan die anafoor. Volgens Reuland en Everaert (2001: 635) kan so 'n indeks beskou word as "perhaps, the sole aspect of a lexical item that is visible for whatever mental faculty assigns reference"; Reuland (2001: 440) beskryf die konsep indeks voorts as "in principle semantic". Daarteenoor stel Chomsky (1995a: 217, vn. 53) dit dat "Indices are basically the expression of a relationship, not entities in their own right"; kyk ook Heinat (2006a: 4).

7. Daar is verskeie definisies van "k-kommandeer" in die literatuur; kyk bv. Chomsky (1981), Haegeman (1994) en Hornstein et al. (2005). Die definisie in (5) is oorgeneem uit Chomsky (1995a: 35). In die terminologie van die standaard-Bindingsteorie (kyk vn. 5) word 'n anafoor $\alpha$ "gebind" deur sy antesedent $\beta$ indien (i) $\beta$ vir $\alpha$ kkommandeer en (ii) $\alpha$ gekö̈ndekseer is met $\beta$. 'n Gebonde anafoor staan in 'n koreferensiële verhouding met sy antesedent. Kyk bv. Lasnik en Hendrick (2003) en Reuland en Everaert (2001: 635-6) vir die rol van $\varphi$ kongruensie, kö̈ndeksering en k-kommandeer in die vaslegging van referensiële verhoudings.

8. As $\gamma$ in (5) 'n maksimale projeksie is, word gesê dat $\beta$ vir $\alpha$ "m-kommandeer"; kyk bv. Chomsky (1995a: 35) en Ouhalla (1999: 194).

9. Die uiting in (6b) is ook anvaarbaar indien die voornaamwoord hom nie-anafories gebruik word om te verwys na iemand anders as die individu wat geïdentifiseer word deur Piet (of Jan).

10. Kyk Chomsky (1995a: 101); kyk ook vn. 5 vir die gebruik van "regerende kategorie" in die bindingsbeginsels van die standaard-Bindingsteorie. 
11. Soos in die geval van "k-kommandeer", bestaan daar verskeie definisies van "regering" in die literatuur; kyk bv. Chomsky (1981, 1982, 1985, 1986), Epstein (1999), Hornstein et al. (2005), Rizzi (1990) en Waher (1991). Die karakterisering in die teks is gebaseer op die definisies in Chomsky (1986: 8; 1995a: 78-92). Kyk vn. 8 vir die term "m-kommandeer" in dié karakterisering. Die klas van moontlike regeerders sluit onder meer die leksikale hoofkategorieë N, V, A en P in, asook die funksionele hoofkategorie I(nfleksie) met die kenmerke [+tempus, +AGR], waar "AGR(eement)" verwys na 'n kompleks van $\varphi$-kenmerke wat betrokke is by subjekwerkwoord-kongruensie in tale soos Engels en Italiaans (kyk Chomsky 1981: 52). Oor die konsep versperring is daar eweneens talle voorstelle in die literatuur; kyk bv. die verwysings hierbo. Vir die doeleindes van die artikel kan volstaan word met die vereenvoudigde idee dat 'n maksimale projeksie wat nie die komplement van ' $n$ hoof is nie, kan dien as 'n versperring vir regering (kyk Chomsky 1995a: 79).

12. Die term "SUBJEK" verwys na die mees prominente nominale element in $\beta$, wat enige van die volgende kan wees (kyk bv. Chomsky 1981: 211-2): die subjek van 'n infinitiewe $\sin$ (Dit is onmoontlik [vir JAN om te wen]), of van 'n NP/DP ([JAN se deelname] is onseker), of van 'n beknopte sin ("small clause", Ek vind [JAN arrogant]), of die AGR-kompleks in die I-hoof van 'n finiete sin (kyk vn. 11). Kyk ook bv. Reuland en Everaert (2001: 637-9) vir die konsep toeganklike SUBJEK.

13. Kyk Hornstein et al. (2005) vir 'n uitvoerige bespreking van die konseptuele en empiriese probleme van die verskillende subteorieë van die GB-teorie. Kyk ook bv. Bennis (1994; 1995), Broekhuis en Den Dikken (1993), Chomsky (1995a: hfste. 2-4, 1995b), Freidin (1997) en Ouhalla (1999: 403-465).

14. Vir die empiriese gebreke van die Bindingsteorie, kyk bv. Reuland en(1995a: 100) Everaert (2001: 641-5), Ouhalla (1999: 416-432), Zwart (2002) en die tersaaklike verwysings in hierdie werke.

15. Kyk bv. Kayne (2002), Heinat (2005, 2006a, 2006b), Lasnik en Hendrick (2003), Reinhart en Reuland (1993), Reuland (2001) en Zwart (2002).

16. Heinat het die analise aanvanklik voorgestel in sy 2005-publikasie, en dit daarna in besonderhede uitgewerk in sy proefskrif (Heinat 2006a). Die sentrale idees van die analise - spesifiek dié rondom $\varphi$-kongruensie en die strukturele onderskeiding tussen refleksiewe en voornaamwoorde - word weergegee in Heinat (2006b). Die uiteensetting hieronder is hoofsaaklik gebaseer op Heinat (2006a, 2006b).

17. Heinat (2006b) se analise van voornaamwoorde en refleksiewe as sintaktiese samestellings is gegrond in die raamwerk van Verspreide Morfologie ("Distributed Morphology") soos uiteengesit in bv. Halle en Marantz (1993); kyk ook Heinat (2006a: hfst. 3) en die verwysings wat daar gegee word. Kyk Zwart (2002: 272-275) vir die idee dat voornaamwoorde en refleksiewe uit dieselfde wortel gevorm word in die loop van 'n sintaktiese afleiding; Zwart (2002: 275) verwys na dié wortel as "the generic variable referential element PRONOUN."

18. Kyk Heinat (2006a: hfst. 3) vir 'n kort bespreking van die interne struktuur van DP's; kyk ook Abney (1987). Volgens Heinat (2006a: 78) is die verskil tussen "the reflexive and the non reflexive [sic] DP ... that the reflexive 
DP is only a DP with a root and a head, and the referential DP is a full DP with (at least) one root and an N head."

19. Die kwessie van die (on)interpreteerbaarheid van kenmerke moet verstaan word teen die agtergrond van hoe die grammatika van ' $n$ taal georganiseer is binne MS. In dié raamwerk bestaan die uitdrukkings wat deur die komputasie-sisteem van 'n grammatika afgelei word optimaal uit twee gepaarde, formele representasies, nl. fonetiese vorm ("phonetic form", PF) en logiese vorm ("logical form", LF). Hierdie representasies - die afvoer van onderskeidelik die fonologiese en semantiese komponente - druk daardie aspekte van klank en betekenis uit wat bepaal word deur die grammatika. PF en LF vorm die toevoer vir twee soorte kognitiewe gebruiksisteme ("performance systems"), nl. sensorimotor-sisteme en denksisteme ("systems of thought"), beide ekstern aan die grammatika. Die gebruiksisteme verkry toegang tot die betrokke representasies by twee afsonderlike raakvlakke met die grammatika: die sensorimotor-sisteme verkry toegang tot PF by die artikulatories-perseptuele raakvlak ("articulatory-perceptual (A-P) interface"), en die denksisteme verkry toegang tot LF by die konseptueelintensionele raakvlak ("conceptual-intentional (C-I) interface"). Om welgevorm te wees by die A-P-raakvlak moet ' $n$ PF-representasie uitsluitlik bestaan uit verwerkbare ("legible") elemente, dit wil sê, dit moet al en slegs daardie kenmerke en strukturele eienskappe bevat wat geïnterpreteer kan word as "instruksies" vir die sensorimotor-sisteme. Dieselfde geld vir 'n LF-representasie wat by die C-I-raakvlak dien as toevoer vir die denksisteme. Kortom, PF-representasies mag slegs foneties-interpreteerbare elemente bevat en LF-representasies slegs semanties-interpreteerbare elemente, 'n beperking wat binne MS uitgedruk word deur die Beginsel van Volle Interpretasie ("Principle of Full Interpretation", FI). 'n Afleiding stort ineen ("crashes") as dit nie voldoen aan FI by een of beide van die raakvlakke nie; andersins konvergeer ("converge") dit.

Kyk bv. Chomsky (1995a: 167-172, 2000), Freidin (1997); Hornstein et al. (2005: hfste. 1 \& 2) vir die organisasie van die grammatika binne MS. Vir die konsep (on)interpreteerbare kenmerk, kyk bv. Adger (2003: hfst. 2), Chomsky (1995a: 219-241, 2005a: 17-8), Collins (2001), Hornstein et al. (2005: hfst. 9) en Radford (2004: 224-6).

20. Hierdie vereiste geld ook vir foneties-oninterpreteerbare kenmerke; in die bespreking hieronder word slegs aandag gegee aan semanties-(on)interpreteerbare kenmerke. Kyk die verwysings in vn. 19 vir die konsepte kenmerkwaarde ("feature value") en waardering van kenmerke ("valuation of features"). Sommige kenmerke het die leksikale eienskap dat hulle inherent oor 'n waarde beskik, terwyl ander weer leksikaal ongewaardeer is en hulle waarde eers in die loop van 'n sintaktiese afleiding verkry. Chomsky (2001: 5, 2005a: 17) stel dit dat (semanties-)oninterpreteerbare kenmerke altyd leksikaal ongewaardeer is. Daarteenoor stel Pesetsky en Torrego (2004) voor dat sommige oninterpreteerbare kenmerke wel leksikaal gewaardeer kan wees, en dat sommge interpreteerbare kenmerke leksikaal ongewaardeer kan wees, 'n voorstel wat sentraal is in Heinat se analise van die onderskeiding tussen refleksiewe en voornaamwoorde; kyk bv. Heinat (2005a: 109).

21. Heinat gebruik die term "T-feature" vir wat in (10) genoem word "K-kenmerk". Volgens hom (2006b: 26) is hierdie kenmerk "basically ... a case feature". Die gebruik van "K-kenmerk" in hierdie artikel is om moontlike verwarring met die konvensionele gebruik van "T" as afkorting vir die funksionele hoof Tempus ("Tense") te 
voorkom. Kyk Heinat (2005a: 115-7) vir die moontlike waardes van T soos dit gebruik word in die term "Tfeature" en spesifiek die idee dat "T is a simple indication of [+/ past] [sic]", ook by nominale uitdrukkings.

22. Aangesien die gewaardeerde K-kenmerk semanties-oninterpreteerbaar is, moet dit geskrap word tydens die oordrag ("transfer") van die afleiding na die semantiese komponent toe; andersins lei dit tot ineenstorting by die C-I-raakvlak. Dit is egter moontlik dat dié kenmerk foneties gerealiseer kan word in ' $\mathrm{n}$ besondere taal; om konvergering by die A-P-raakvlak te verseker, moet dit dus sigbaar wees vir fonetiese interpretasie tydens oordrag na die fonologiese komponent toe. Volgens Chomsky (2005b: 21) vind die twee tipes oordragbewerkings gelyktydig op dieselfde stadia in 'n afleiding plaas. Die standaard-hipotese is dat dié stadia tegnies bekend as "fases" ("phases") - CP en $v \mathrm{P}$ is. Oordrag hou in dat die komplement van 'n fase-hoof gekanaliseer word na die fonologiese en semantiese komponente toe sodra 'n volgende fase-hoof in die struktuur saamgestel word. Volgens die versie van fase-teorie in Chomsky (2001, 2005b), word 'n VP bv. eers oorgedra wanneer die volgende fase-hoof bokant die klein- $v$, dit wil sê die C, saamgestel word in die struktuur (kyk ook vnn. 33 en 39). Die gevolg van oordrag is dat die betrokke komplement en sy onderdele nie meer beskikbaar is vir verdere sintaktiese bewerkings nie. Kyk bv. Chomsky (2000: 106-7, 2001: 11-14, 2005b: 9-10, 2006: 11-14), Heinat (2006a: 7-13, hfst. 2), Hornstein et al. (2005: 346-51) en Radford (2004: 224-30, hfst. 10).

23. Kyk bv. Chomsky (2000: 122-6, 2001: 3-6, 2004a: 113-114), Heinat (2006a: hfst. 2, 2006b: 20-1), Hornstein et al. (2005: 317-323) en Radford (2004: 218-226) vir die konsepte soeker en teiken asook die idee dat kongruensie tot stand kom deur die vaslegging van 'n soeker-teiken-verhouding.

24. Heinat (2006a: 110, 2006b: 29) verwys na onder meer Pesetsky en Torrego (2004) vir hierdie aanname. Die afkortings "g" en "o" word hier en verderaan gebruik vir onderskeidelik "gewaardeer" en "ongewaardeer".

25. Die gebruik van 'n getal soos [2], [5], ens. in dié soort notasie is volgens Heinat (2006a: 110; 2006b: 29) "just an indication of a shared value and has no significance in the actual valuation of ... features." Kyk afdeling 4 hieronder in verband met die gebruik van sulke getalle.

26. Volgens Chomsky (2001: 6) het klein- $v^{\prime}$ s en T's nie K-kenmerke nie, maar wel die inherente eienskap dat hulle 'n spesifieke waarde gee aan die K-kenmerk van die DP waarmee hulle $\varphi$-kongrueer, onderskeidelik akkusatief en nominatief. Heinat (2006a: 39) skep anvanklik die indruk dat hy dié voorstel van Chomsky aanvaar; sy (2006a: hfst. 5, 2006b: 29-34) bespreking van K-kenmerkwaardering laat egter geen twyfel dat klein$v$ 's en T's wel gewaardeerde K-kenmerke het binne sy analise nie.

Vir die konsep klein-v, kyk bv. Adger (2003: 131-46), Radford (2004: 262-83) en Hornstein et al. (2005: 92110). Chomsky (2006: 12) maak die aanname dat "verbal phrases are of the form $v$-VP, where $v$ can be $v^{*}$, the functional category that heads verb phrases with full argument structure"; hy (2005b: 10) meld "transitive and experiencer constructions" as voorbeelde van frases met ' $n v^{*}$ as hoof. Daarteenoor vorm $v$ die hoof van "unaccusatives and passives", volgens Chomsky $(2006: 12,15)$. Die onderskeid tussen die twee soorte klein- $v$ 's word eenvoudigheidshalwe buite rekening gelaat in die huidige bespreking (maar kyk afdeling 4 hieronder). 
27. In so 'n geval maak die betrokke hoof se ongewaardeerde kenmerk deel uit van die frase se kategorie-etiket, wat beteken dat die hoof indirek betrokke is by die bepaling van die frase se "soekerskap".

Heinat (2006a: hfst. 2) bied verskeie argumente (i) teen die aanname dat slegs hoofde kan optree as soekers en (ii) ter ondersteuning van die hipotese dat frases ook soekers kan wees; 'n bespreking van dié argumente val egter buite die bereik van hierdie artikel. In aansluiting by laasgenoemde hipotese maak Heinat (2006b: 21) die aanname dat "all externally merged syntactic objects with unvalued features are probes"; kyk ook Heinat (2006a: 105). Hiervolgens kan ' $n$ gepaste element $A$ as 'n soeker optree wanneer dit die eerste keer met 'n sintaktiese objek B saamgestel word, dit wil sê, wanneer A die afleiding binnekom as 'n element ekstern aan B. Die bewerking waardeur ' $n$ element "van buite af" saamgestel word met 'n sintaktiese objek, staan bekend as "eksterne saamstel" ("external merge"). Die aanname sou ook kon impliseer dat 'n element A wat deel vorm van 'n sintaktiese objek B nie as 'n soeker kan optree indien dit binne B skuiwing ondergaan het nie. Met "skuiwing" word hier bedoel dat A gekopieer en in 'n ander posisie in B saamgestel word, met die kopie wat agterbly in A se aanvanklike posisie; dié bewerking staan bekend as "interne saamstel" ("internal merge"). Heinat (2006b) brei nie uit oor die presiese inhoud en die konsekwensies van die bogenoemde aanname nie. Vir die onderskeiding tussen eksterne en interne saamstel, kyk bv. Chomsky (2005a: 12) en Radford (2004: 161).

28. Kyk Heinat (2006a: 110-1) vir die kongruensie tussen die DP en sy verskillende onderdele. Soos gemeld in vn. 25 is die gebruik van ' $n$ getal soos [2], [5], ens. bloot ' $n$ manier om aan te dui dat twee of meer kenmerke deur kongruensie 'n gegewe waarde (wat 'n "geen-waarde" kan wees) deel. Kyk ook die bespreking in afdeling 4.

29. In die proses word die K-kenmerk van die DP se onderdele (kyk (13) hierbo) ook gewaardeer as akkusatief; kyk Heinat (2005a: 110-3). Dié kongruensie-bewerkings word nie aangedui in (15) nie; die soliede pyl dui op 'n soeker-teiken-verhouding.

30. Vir die doel van vereenvoudiging word daar nie in hierdie artikel aandag gegee aan die moontlike interne saamstel - om watter rede ook al - van (i) die V se objek/komplement in die spesifiseerderposisie van die VP/vP en (ii) die $\mathrm{V}$ en die klein- $v$ nie. Kyk vnn. 27 en 31.

31. Die rand-kenmerk van ' $n$ hoof $H$ aktiveer die verskuiwing van ' $n$ frase $F$ na ' $n$ spesifiseerderposisie van $H$, of in meer tegniese terme, die interne saamstel (kyk vn. 27) van $\mathrm{F}$ in 'n posisie aan die linker-buiterand van $\mathrm{H}$. Chomsky (2005b: 2, 115) stel dit dat so 'n kenmerk "automatically available" is vir leksikale items en dat dit die verskuiwing van 'n frase toelaat "without feature matching" (2005a: 19). Hy (2006: 6) maak verder die aanname dat 'n rand-kenmerk "undeletable, a property of UG" is. 'n Konsekwensie van dié aanname is dat dit, minstens in beginsel, moontlik is dat ' $n$ hoof meer as een spesifiseerderposisie kan hê: een wat bv. ontstaan deur eksterne saamstel - soos in die geval van die subjek-DP in (16) - en een of meer buite-spesifiseerders ("outer SPECs") wat afgedwing word deur die hoof se rand-kenmerk. Heinat maak nie gebruik van die konsep rand-kenmerk nie; in sy (2006a: 45-7) analise van raising-strukture meld hy bloot dat die subjek-DP in die infinitiewe komplement van 'n raising werkwoord soos seem "moves up to [the SPEC of - JO] T to satisfy T's EPP feature" (kyk ook Heinat 2006b: 32-3). Die uitdrukking "EPP" ("Extended Projection Principle") verwys hier na die beginsel, aanvanklik voorgestel binne GB-teorie, dat elke sin (dit wil sê, TP/IP) 'n spesifiseerder moet hê, normaalweg die 
afgeleide posisie van 'n subjek; kyk bv. Chomsky (1982: 10; 2000: 102), Ouhalla (1999: 124-6) en Radford (2004: 64).

In Afrikaanse hoofsinne met een of meer hulpwerkwoorde staan die objek-DP links van die V (bv. Jan het HOM gehaat); dit is ook die geval in bysinne met 'n waarneembare komplementeerder (bv. Ek twyfel of Jan HOM haat). Hierdie feite kan verklaar word deur aan te neem dat, soos die T, 'n klein-v (en moontlik ook ' $\mathrm{n}$ V) beskik oor 'n rand-kenmerk wat verskuiwing oftewel interne saamstel van die objek-DP aktiveer. Dié aanname word vir die doel van vereenvoudiging nie in (16) en verdere soortgelyke strukture geïnkorporeer nie.

32. Die interne struktuur van die subjek-DP word eenvoudigheidshalwe nie weergegee in (17) nie.

33. Vir ' $n$ algemene karakterisering van komplementeerders (C's), kyk bv. Adger (2003: 289-302) en Radford (2004: 44-8). Chomsky (2006: 14) beweer dat T's inherent geen tempus- en $\varphi$-kenmerke bevat nie, maar dat dié kenmerke toegeken word wanneer ' $\mathrm{n} T$ deur ' $\mathrm{n}$ bepaalde $\mathrm{C}$ geselekteer word: " $\mathrm{T}$ bears these features if and only if it is selected by C, hence it should inherit these from C". Elders (2005a: 18) stel hy dit dat "the phase head C may be the locus of agreement, selecting $T$ and assigning it (unvalued) $\varphi$-features" (kyk ook Chomsky 2001: 8-9, 2005b: 10-1, 21-3, 2006: 13-8). Die implikasie van hierdie voorstelle is dat, soos Chomsky (2005b: 21) dit stel, "T operates as a probe only derivatively by virtue of its relation to C"; kyk ook vn. 39. In hierdie artikel word nie verder ingegaan op die kenmerksamestelling van C's en die hipotese dat 'n T se kenmerke deur die betrokke C bepaal word nie.

34. Die interne struktuur van die objek-DP word vir die doel van vereenvoudiging nie verder aangetoon nie.

35. Heinat (2206a: 113) stel dit dat "The unvalued T features [d.i. K-kenmerke - JO] inside the subject DP make the DP (or NP) active, and a potential goal for T's probe." Dat die NP aktief is, is onproblematies: dit bevat immers 'n ongewaardeerde K-kenmerk. Die idee dat die DP aktief bly bloot omdat dit 'n aktiewe NP as onderdeel bevat, is egter problematies in die lig van die algemene aanname dat 'n element waarvan al die kenmerke gewaardeer is (soos hier die geval is met die DP-etiket) onaktief is vanuit die oogpunt van verdere soeker-teiken-verhoudings. Dié kwessie word verder bespreek in afdeling 4 hieronder; vir huidige doeleindes, egter, word volstaan met die hipotese dat die DP-etiket in die subjekposisie in (23) onaktief word sodra sy Kkenmerk gewaardeer is deur die klein- $v$.

36. Heinat (2006a: 111-7) stel dit duidelik dat die subjek-DP se K-kenmerk betrokke is by twee waarde-kettings. Hy (2006a: 113) verwys na hierdie K-waardes as "[T] $]_{\mathrm{a}}$ en "[T]b", onderskeidelik toegeken deur die $\mathrm{T}$ en die klein- $v$; elders (2006a: 116) gebruik hy die terme " $\mathrm{T}_{\mathrm{T}}$ " en " $\mathrm{T}_{v}$ ".

37. Dié twee werke was ongelukkig nie beskikbaar by die skryf van hierdie artikel nie.

38. Kyk bv. Chomsky (2001: 13-14, 2005b: 9-10, 2006: 11), Hornstein (2005: 348-351) en Radford (2004: 224, hfst. 10) vir die inhoud en motivering van die PIC; kyk ook vnn. 22 en 31. 
39. Soos genoem in vn. 33, stel Chomsky (2005b: 10-1, 21-3, 2006: 13-8) voor dat die kategorie $\mathrm{T}$ in finiete sinne op sigself nie beskik oor tempus- en $\varphi$-kenmerke nie, maar dat die $\mathrm{T}$ hierdie kenmerke erf ("inherit") van die $\mathrm{C}$ waardeur dit geselekteer word, dit wil sê, die hoof waarmee die TP ekstern saamgestel word. Hy (2005b: 10) stel dit soos volg ("ECM" verwys na "Exceptional Case Marking"-strukture soos John believed [her to be a liar]; kyk bv. Haegeman (1994: 169-71)):

(i) ... for T, $\varphi$-features and Tense appear to be derivative, not inherent: basic tense and also tense-like properties (e.g., irrealis) are determined by $\mathrm{C}$ (in which they are inherent ...) ... In the lexicon, $\mathrm{T}$ lacks these features. $\mathrm{T}$ manifests the basic tense features if and only if it is selected by $\mathrm{C} \ldots$; if not, it is a raising (or ECM) infinitival, lacking $\varphi$-features and basic tense. So it makes sense to assume that Agree- and Tense-features are inherited from $\mathrm{C}$, the phase head. If $\mathrm{C}$ - $\mathrm{T}$ agrees with the goal DP, the latter can remain in-situ under longdistance Agree, with all uninterpretable features valued; or it can raise as far as SPEC-T [afgedwing deur T se rand-kenmerk - JO], at which point it is inactivated, with all features valued.

Die voorstel in (i) het 'n potensieel ernstige konsekwensie vir Heinat se analise van strukture soos die een in (27). Om dit kort te stel, indien die $\mathrm{T}$ van die $\mathrm{C}$ afhanklik is vir sy tempus- en $\varphi$-kenmerke, kan die $\mathrm{T}$ nie as 'n soeker optree alvorens die C saamgestel word in die struktuur nie. Wanneer die C ('n fase-hoof) egter saamgestel word, sou mens verwag dat die VP-komplement van die klein- $v$ (ook 'n fase-hoof) dadelik oorgedra word na die twee raakvlakke toe (kyk vn. 22). Dit sou egter beteken dat die objek-DP nie meer beskikbaar is as 'n moontlike teiken vir die T nie. ' $n$ Uitvoerige bespreking van die voorstel in (i), en van die konsekwensies wat dit het vir Heinat se analise, val egter buite die bereik van hierdie artikel. Vir die doel van vereenvoudiging word hier bloot aangeneem dat die T (as deel van 'n C-T-"ketting") wel in 'n soeker-teiken-verhouding kan tree met die objek-DP in 'n struktuur soos (27).

40. Die term "konstruksie" word hier en verder op 'n informele, nie-teoretiese manier gebruik, in aansluiting by die volgende opmerkings van Chomsky (1995a: 170):

The notion of grammatical construction is eliminated [in minimalist syntax - JO], and with it, constructionparticular rules. Constructions such as verb phrase, relative clause, and passive remain only as taxonomic artifacts, collections of phenomena explained through the interaction of the principles of UG, with the values of parameters fixed.

41. Kyk bv. Chomsky (1995a: 232-5, 277-286, 1995b: 395), Collins (2001) en Lasnik (1999, 2001).

42. Volgens die tipologie in (10) besit 'n D ongewaardeerde $\varphi$-kenmerke en ' $n N$ gewaardeerde $\varphi$-kenmerke. In ' $n$ struktuur van die tipe in (13) word die $\varphi$-waardes van die D, en dus ook van die DP waarvan dit die hoof vorm, in 'n kongruensie-verhouding verskaf deur die N(P) waarmee die D saamgestel word. Die uitdrukkings "(DP-) interne waardering" en "intern-gewaardeerde kenmerke" word hieronder gebruik om dié tipe $\varphi$-waardering te onderskei van die tipe waar die DP se $\varphi$-waardes verskaf word deur 'n soeker-DP hoër op in die sinstruktuur.

43. Kyk ook bv. Chomsky (1995a: 228-9, 2000: 113-4, 2005b: 5), Freidin (1997: 573-7) en Radford (2004: 78$80)$. 
44. Heinat (2006a, 2006b) gee nie aandag aan die semantiese meganismes wat ' $n$ rol speel in die regulering van referensiële verhoudings nie. Maar dit is juis dié meganismes wat uiteindelik moet bepaal of ' $n$ element $B$ geïnterpreteer word as koreferensieel met ' $n$ element A of nie, dit wil sê - in die terminologie van die standaardBindingsteorie (kyk vnn. 5 en 7) - of B gebind ("bound") of vry ("free") is. Heinat (2005: 43) suggereer wel die volgende definisies in dié verband:

Bound: A binds B, B, a root pronoun [oftewel 'n DP van die tipe in (35) - JO], iff there is an agree relation between $\mathrm{A}$ and $\mathrm{B}$.

Free: not bound.

Gegee hierdie definisies, is die vraag steeds hoe die betrokke semantiese meganismes kan vasstel (i) of 'n DP 'n "root pronoun" is en (ii) of daar ' $n$ kongruensie-verhouding tussen twee DP's bestaan (teenoor die moontlikheid dat hulle $\varphi$-kenmerkwaardes net toevallig dieselfde is); die voorstelle in (36) en) (37) is 'n poging om die nodige inligting meer eksplisiet te stel.

45. Hierdie formulering sluit nie die moontlikheid uit dat die DP wel geïnterpreteer kan word as koreferensieel met ' $n$ gepaste uitdrukking buitekant $F$ nie (selfs een in ' $n$ ander uiting in die wyer kommunikasie-konteks). Die belangrike punt is dat die DP in $F$ noodwendig nie-anafories is omdat dit nie in ' $\mathrm{n} \varphi$-kongruensie-verhouding staan met ' $n$ soeker-DP nie. In hierdie artikel word aangeneem dat die (opsionele) anaforiese gebruik van 'n DP nie gereguleer word deur sintaktiese of semantiese meganismes nie, maar eerder deur een of ander pragmatiese beginsel(s); kyk bv. Sperber en Wilson (1995: hfst. 4) en Sinclair en Winckler (1991).

46. Die NTC, volgens Chomsky (2005a: 11), "sharply reduces computational load: what has once been constructed can be 'forgotten' in later computations, in that it will no longer be changed." Kyk ook Chomsky (2004a: 5-6, 2005b: 5).

47. Soos genoem in afdeling 2, word stap (ii) voorveronderstel deur die prosedure in (39).

48. Die twee tipes uitings vertoon ook fonologiese ooreenkomste en verskille. Wanneer die uitings in $(1 \mathrm{a}, \mathrm{b}) \mathrm{met}$ die normale, nie-nadruklike, sinsklempatroon uitgespreek word, val die hoofklem by albei op die objek (Jan haat homsélf, Jan haat hóm); by (40a,b), daarenteen, val die hoofklem normaalweg op die werkwoord (Jan versét homself, Jan versét hom). Die uiting in (40a) kan skynbaar ook uitgespreek word met die hoofklem op die objek (Jan verset homsélf), maar in dié geval word die self-agtervoegsel waarskynlik juis vir nadruk gebruik; kyk Ponelis (1979: 81). Kyk ook Büring (2004: 22) vir die nie-vatbaarheid vir beklemtoning as een van die diagnostiese toetse om anaforiese uitdrukkings te identifiseer.

49. Afrikaans het verskeie uitsluitlik refleksiewe werkwoorde, onder meer afsloof, gedra, misgis, ontferm, verbeel, verdiep, vergaap, verlustig en verspreek; kyk Ponelis (1979: 227-30).

50. Volgens Ponelis (1979: 81) kan persoonlike voornaamwoorde, met die uitsondering van dit, "tot emfatiese/ nadruklike voornaamwoorde versterk word deur self"; hy (1979: 88) merk voorts op dat die gebruik van die 
simplekse vorm van die refleksiewe voornaamwoord "Onder Engelse invloed ... ook in die skryftaal aan die wyk [is] voor 'n vorm met -self". Kyk Büring (2004: 21-23) vir die gebruik van -self in Engels, en Reuland en Everaert (2001: 21-33) vir 'n uitvoerige bespreking van die leksikale en sintaktiese eienskappe van komplekse en simplekse anafore in Duits, Engels, Fries en Nederlands. Heinat (2006a: 89-91) bied verskeie argumente teen die voorstel van o.m. Reinhart en Reuland (1993) dat die Engelse morfeem self (en die ooreenstemmende morfeem in bv. Sweeds en Oudengels) funksioneer as 'n refleksiviseerder. Hy (2006a: 91) kom tot die slotsom dat "the 'self'-morpheme indicates emphasis and not reflexivity." Kyk ook Zwart (2002: 273) vir die idee dat "anaphors can be analyzed as pronouns with added focus markers", waar -self so 'n fokusmerker is.

51. Die kwalifikasie "normaalweg" is belangrik hier. Afrikaans besit naamlik 'n subklas oorganklike werkwoorde wat nie uitsluitlik refleksief is nie, maar wat tog sowel komplekse as simplekse anafore neem as objek. Enkele voorbeelde is die volgende:

(i) a. $\operatorname{Jan}_{\mathrm{i}}$ skeer (skrop, was) homself $\mathrm{i}_{\mathrm{i}} / \mathrm{hom}_{\mathrm{i}}$.

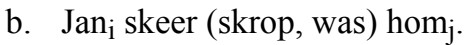

(ii) a. Marie $\mathrm{i}_{\mathrm{i}}$ het haarself $\mathrm{f}_{\mathrm{i}} /$ haar $_{\mathrm{i}}$ opgemaak (gegrimeer, opgedollie, aangetrek).

b. Marie $e_{i}$ het haar $r_{j}$ opgemaak (gegrimeer, opgedollie, aangetrek).

(iii) a. Hy $y_{\mathrm{i}}$ kon homself $\mathrm{f}_{\mathrm{i}} / \mathrm{hom}_{\mathrm{i}}$ nie keer (beweeg, draai, lig, roer) nie.

b. Hy $\mathrm{k}_{\mathrm{i}}$ kon hom $\mathrm{j}$ nie keer (beweeg, draai, lig, roer) nie.

'n Beskrywing van dié subklas werkwoorde val buite die bereik van die artikel en word gelaat as 'n onderwerp vir verdere studie. Kyk Ponelis (1979: 82-3, 87) vir enkele opmerkings.

52. In Bindingsteorie word dié inligting uitgedruk met die leksikale kenmerke [+a, -p]; kyk afdeling 2.

53. Met "opsioneel oorganklik" (of "nie-uitsluitlik oorganklik") word bedoel dat die werkwoord 'n sintaktiese objek kán selekteer (bv. Jan drink 'n bottel wyn), maar nie hóéf te selekteer nie (bv. Jan drink). In die geval van uitings waar 'n verplig (of uitsluitlik) oorganklike werkwoord in 'n faktitiewe refleksiewe konstruksie gebruik word, is vlotsprekers se oordele dikwels nie ferm nie; dit wil egter voorkom of sulke uitings - bv. ${ }^{?}{ }^{*} \operatorname{Jan}_{i}$ vermoor hom $(\text { self })_{i}$ dood, ${ }^{2}{ }^{*}$ Marie $_{i}$ beseer haar $(\text { self })_{i}$ moedeloos, ${ }^{? *}{ }^{*} n_{i}$ nooi/verset hom $(\text { self })_{i}$ stokflou - beoordeel word as minstens minder aanvaarbaar as dié met onoorganklike of opsioneel oorganklike werkwoorde.

54. Die refleksief kan 'n morfologies simplekse vorm (hom, haar, ens.) of komplekse vorm (homself, haarself, ens.) hê, soos geillustreer in (42a)-(44a). Kyk egter vn. 50 vir Ponelis (1979) se opmerkings oor die gebruik van die komplekse self-vorm in Afrikaans. In die bespreking hieronder van die voorbeelde in (42)-(44) word voortaan net die simplekse vorm van die refleksief gebruik.

55. Kyk bv. Belletti (2001: 497-8), Bowers (2001: 300-4), Haegeman (1994: 59, 123-6, 171-3) en Ouhalla (1999: 129-30) vir die tematiese en sintaktiese eienskappe van beknopte sinne ("small clauses"). 
56. Wat betref die struktuur van beknopte sinne, stel Bowers (2001: 301) dit dat "there are basically only two alternatives: (i) the subject of a predicative expression XP of category $\mathrm{X}$ is in [Spec, $\mathrm{X}]$; (ii) there is a functional category $\mathrm{F}$ such that the predicative expression XP is the complement of $\mathrm{F}$ and its subject is in [Spec, F]." Bowers argumenteer vir die tweede benadering, die een wat weergegee word in (44). Hy (2001: 302) stel verder die kategorie-etiket "Pr" voor vir F, waar Pr die predikasionele funksie van die konvensionele kategorie I (of T in latere versies van frasestruktuur-teorie) verteenwoordig: "The category label Pr is simply a mnemonic for either 'predicate' or 'predication,' depending on whether the focus is on its categorical or its relational function." Uit ' $n$ sintaktiese oogpunt is Pr 'n funksionele kategorie wat enige XP as komplement kan neem. 'n Alternatiewe moontlikheid is om F te analiseer as Agr ("Agreement") - dit wil sê, as 'n "gereduseerde" I/T-hoof, een sonder ' $n$ tempus-kenmerk; kyk bv. Haegeman (1994: 171-3) en vn. 11. Aangesien dié kwessies buite die bereik van die artikel val, word hier volstaan met die ongespesifiseerde kategorie-etiket $\mathrm{F}(\mathrm{P})$.

57. Die aanname dat 'n A(P) beskik oor 'n K-kenmerk en $\varphi$-kenmerke is gebaseer op die feit dat adjektiewe in verskeie tale geïnflekteer word vir kasus en/of persoon/getal/geslag. Kyk bv. Heinat (2005a: 50, 110-1) vir voorbeelde uit Fins, Latyn, Pools en Sweeds; kyk ook bv. Ouhalla (1999: 408-10) en Spencer (2001). Die aanname dat die $\mathrm{F}$ nie 'n K-kenmerk het nie impliseer dat dit, anders as die $\mathrm{T}$ en die klein- $v$, nie betrokke is by kasustoekenning/K-kenmerkwaardering nie.

58. Vir die doel van vereenvoudiging word hier nie aandag gegee aan die interne struktuur van die AP nie.

59. In die strukture hieronder word die kenmerke van FP, $v$ P en TP geriefshalwe net op elkeen se hoof aangedui.

60. Nog soortgelyke voorbeelde is $J_{a n}$ lag hom ${ }_{i}$ 'n papie/'n boggel, Die slot ${ }_{i}$ hou hom $_{i}$ vandag weer 'n heelagter, Marie $_{i}$ het haar ${ }_{i}^{\prime} n$ wrak/'n zombie gewerk.

61. Die interne struktuur van die NP word nie verder hier bespreek nie.

62. Kyk Heinat (2005a: 100-2) vir 'n kort bespreking van Zwart (2002) se voorstelle.

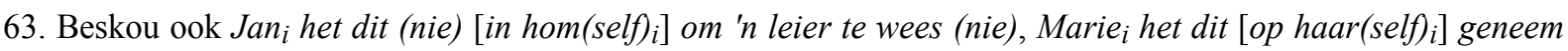
om jou te help. Let op dat die refleksief in hierdie voorbeelde die morfologies simplekse vorm kan hê; trouens, die gebruik van die komplekse self-vorm is hier waarskynlik óf vir nadruk óf ' $n$ geval van beïnvloeding deur Engels (kyk vn. 50 vir Ponelis (1979) se opmerkings in hierdie verband). Die voorbeelde in (59a), daarenteen, is slegs aanvaarbaar as die refleksief die komplekse self-vorm het.

64. Hier, en ook in (61) en (62), het die refleksief die genitiewe kasusvorm. 


\section{Verwysings}

Abney, S. 1987. The English noun phrase in its sentential aspect. Dissertation, Massachusetts Institute of Technology. Distributed by MIT Working Papers in Linguistics.

Adger, D. 2003. Core syntax. A minimalist approach. Oxford: Oxford University Press.

Aronoff, M. and J. Rees-Miller (eds). 2001. The handbook of linguistics. Oxford: Blackwell.

Baltin, M. and C. Collins (eds). 2001. The handbook of contemporary syntactic theory. Oxford: Blackwell.

Belletti, A. (ed). 2004. Structures and beyond: The cartography of syntactic structures, Vol. III. Oxford: Oxford University Press.

Bennis, H. 1994. Waar is het werkwoord? Deel I: Het minimalistische kader. Spektator 23(3): 171-190.

Bennis, H. 1995. Waar is het werkwoord? Deel II: Antisymmetrie. Spektator 24(2): 130-146.

Bowers, J. 2001. Predication. In M. Baltin and C. Collins (eds). pp. 299-333.

Broekhuis, H. and M. den Dikken. 1993. Chomsky's minimalistische programma. Tabu. Bulletin voor Taalwetenschap Groningen 23(4).

Büring, D. 2004. Binding theory. Cambridge: Cambridge University Press.

Chomsky, N. 1981. Lectures on government and binding. Dordrecht: Foris.

Chomsky, N. 1982. Some concepts and consequences of the theory of government and binding. Cambridge, Mass.: MIT Press.

Chomsky, N. 1985. Knowledge of language: its nature, origin and use. New York: Praeger.

Chomsky, N. 1986. Barriers. Cambridge, Mass.: MIT Press.

Chomsky, N. 1995a. The minimalist program. Cambridge, Mass.: MIT Press.

Chomsky, N. 1995b. Bare phrase structure. In G. Webelhuth (ed). pp. 385-439.

Chomsky, N. 2000. Minimalist inquiries: the framework. In R. Martin, D. Michaels and J. Uriagereka (eds). pp. 89-156.

Chomsky, N. 2001. Derivation by phase. In M. Kenstowicz (ed). pp. 1-52.

Chomsky, N. 2004a. Beyond explanatory adequacy. In A. Belletti (ed). pp. 104-131.

Chomsky, N. 2004b. Language and mind: current thoughts on ancient problems. In L. Jenkins (ed). pp. 379-405.

Chomsky, N. 2005a. Three factors in language design. Linguistic Inquiry 36: 1-22.

Chomsky, N. 2005b. On phases. Manuscript, September 2005. To appear in C. Otero et al. (eds). Foundational ossues in linguistic theory. Cambridge, Mass.: MIT Press. 
Chomsky, N. 2006. Approaching UG from below. Manuscript of a paper read at a conference in Berlin, Germany, April 2006.

Chomsky, N. and H. Lasnik. 1995. The theory of principles and parameters. In N. Chomsky. pp. 13-127.

Collins, C. 2001. Economy conditions in syntax. In M. Baltin and C. Collins (eds). pp. 45-61.

Epstein, S. 1999. Un-principled syntax. The derivation of syntactic relations. In S. Epstein and N. Hornstein (eds). pp. 317-345.

Epstein, S. and N. Hornstein (eds). 1999. Working minimalism. Cambridge, Mass.: MIT Press.

Epstein, S. and T. Seely (eds.). 2002. Derivation and explanation in the minimalist program. Oxford: Blackwell.

Freidin, R. 1997. Review article: The minimalist program. Language 73(3): 571-582.

Haegeman, L. 1994. Introduction to government and binding theory. Second edition. Oxford: Blackwell.

Hale, K. and S. Keyser (eds.). 1993. The view from Building 20. Cambridge, Mass.: MIT Press.

Halle, M. and A. Marantz. 1993. Distributed morphology and the pieces of inflection. In K. Hale and S. Keyser (eds). pp. 111-176.

Heinat, F. 2005. Reflexives in a phase based syntax. Working Papers in Scandinavian Syntax 75: 37-54. Department of Scandinavian Languages, Lund University.

Heinat, F. 2006a. Probes, pronouns, and binding in the minimalist program. Dissertation, Lund University.

Heinat, F. 2006b. Probing phrases, pronouns, and binding. The Department of English in Lund: Working Papers in Linguistics 6: 19-37.

Hendrick, R. (ed). 2003. Minimalist syntax. Oxford: Blackwell.

Hornstein, N., J. Nunes and K. Grohmann. 2005. Understanding minimalism. Cambridge: Cambridge University Press.

Jenkins, L. (ed). 2004. Variation and universals in biolinguistics. Amsterdam: Elsevier.

Kayne, R. 2002. Pronouns and their antecedents. In S. Epstein and T. Seely (eds). pp. 133166.

Kenstowicz, M. (ed.). 2001. Ken Hale: a life in language. Cambridge, Mass.: MIT Press.

Lasnik, H. 1999. On feature strength: three minimalist approaches to overt movement. Linguistic Inquiry 30(2): 197-217. 
Lasnik, H. 2001. Derivation and representation in modern transformational syntax. In M. Baltin and C. Collins (eds). pp. 62-88.

Lasnik, H. and R. Hendrick. 2003. Steps toward a minimal theory of anaphora. In R. Hendrick (ed). pp. 124-151.

Martin, R., D. Michaels and J. Uriagereka (eds.). 2000. Step by step. Essays on minimalist syntax in honour of Howard Lasnik. Cambridge, Mass.: MIT Press.

Ouhalla, J. 1999. Introducing transformational grammar. From principles and parameters to minimalism. Second edition. London: Arnold.

Pesetsky, D. and E. Torrego. 2004. The syntax of valuation and the interpretability of features. Manuscript. Cambridge, Mass.: MIT. [soos na verwys in Heinat (2006a; 2006b)]

Pesetky, D and E. Torrego. 2005. Features, case and syntactic categories. Lecture hand-out, Lund University, March 2005. [soos na verwys in Heinat (2006a; 2006b)]

Ponelis, F. 1979. Afrikaanse sintaksis. Pretoria: Van Schaik.

Radford, A. 2004. English syntax: an introduction. Cambridge: Cambridge University Press.

Reinhart, T. 1983. Anaphora and semantic interpretation. Chicago: University of Chicago Press.

Reinhart, T. and E. Reuland. 1993. Reflexivity. Linguistic Inquiry 24: 657-720.

Reuland, E. 2001. Primitives of binding. Linguistic Inquiry 32: 439-492.

Reuland, E. and M. Everaert. 2001. Deconstructing binding. In M. Baltin and C. Collins (eds). pp. 634-669.

Rizzi, L. 1990. Relativized minimality. Cambridge, Mass.: MIT Press.

Sinclair, M and W. Winckler. 1991. Relevance theory. Explaining verbal communication. Stellenbosch Papers in Linguistics Plus (SPIL PLUS) 18. Department of General Linguistics, Stellenbosch University.

Smith, N. 1998. Does Chomsky exist? Glot International 3(1): 9.

Smith, N. 1999. Chomsky: Ideas and ideals. Cambridge: Cambridge University Press.

Spencer, A. 2001. Morphology. In M. Aronoff and J. Rees-Miller (eds). pp. 214-237.

Sperber, D. and D. Wilson. 1995. Relevance. Communication and cognition. Second edition. Oxford: Blackwell.

Waher, H. 1991. Oor grense, kettings, en lisensies. 'n Sleutel tot Chomsky se teorie van grammatika. Stellenbosch Papers in Linguistics Plus (SPIL PLUS) 16. Departement Algemene Taalwetenskap, Universiteit Stellenbosch. 
Webelhuth, G. (ed). 1995. Government and binding theory and the minimalist program. Principles and parameters in syntactic theory. Oxford: Blackwell.

Zwart, J-W. 2002. Issues relating to a derivational theory of binding. In S. Epstein and T. Seely (eds). pp. 268-304. 